\title{
A NON STATIONARY BOX MODEL TO DETERMINE RESIDUAL FLUXES IN A PARTIALLY MIXED ESTUARY, BASED ON BOTH THERMOHALINE PROPERTIES. APPLICATION TO THE RIA DE AROUSA (NW SPAIN).
}

\author{
G. Rosón, X.A. Alvarez-Salgado and Fiz F. Pérez. \\ Instituto de Investigaciones Marinas, C.S.I.C. Eduardo Cabello, 6. 36208 Vigo, Spain.
}

Keywords: Residual circulation. Positive circulation. Reversal circulation. Box model. Upwelling. Downwelling. Salt balance. Heat balance. Ria de Arousa; NorthWest Spain.

\begin{abstract}
An improved two-layered box model for calculating the residual fluxes in a Spanish ria is developed. This kinematic bidimensional model has two characteristics that make it different to previous ones. Firstly, for calculating the horizontal and vertical velocities and also vertical diffusion coefficients it takes into account the distribution not only of salinity but also of temperature. Evaluation of both river discharge and heat exchange between water surface and atmosphere is required. Two sets of fluxes are computed, one for the distribution of salinity, and another for that of temperature. They are then weight-averaged according to the vertical gradient of both properties. Secondly, and due to the high density of sampling (twice a week), it is possible to introduce the non-stationary term in the convection-diffussion equation; thus, time variations of both conservative tracers are taken into account. Coherent solutions of equations are obtained in strong upwelling-downwelling and/or very low river volume situations where the estuary behaves nearly as well-mixed, and salt balance-non stationary previous box models were inapplicable (Otto, 1975; Elliott, 1976a; Elliott 1976b; González et al, 1979; Prego et al, 1990; Prego \& Fraga, 1992). The strong coupling between estuarine circulation and upwelling is shown. An equation is proposed in order to quantify this relationship. On the hypothesis of linear variation of thermohaline properties with time, fluxes at the intermediate time between two samplings are also calculated. Comparison of salinity between two stations at the mouth of the ria, allows the
\end{abstract}


computation of the correction due to Coriolis outward flux deflection, which was then applied to the whole ria.

\section{Introduction}

Ria de Arousa (figure 1) is the most extensive (length $33.1 \mathrm{~km}$, surface $2.39 \cdot 10^{8} \mathrm{~m}^{2}$, capacity $4.8 \cdot 10^{9} \mathrm{~m}^{3}$ ) of the four Rias Baixas. They are sited in the North West of the Iberian Peninsula. They are all partially mixed (Dyer, 1973; Beer, 1983) and positive estuaries with a two-layer residual estuarine circulation (Fraga \& Margalef, 1979). This situation implies the existence of two residual currents, one shelfward, at the surface, and the compensation one at depth (in opposite direction). This circulation determines the longitudinal velocity field $(u)$. However, as will be seen in this work, the existence of persistent southerly winds over the shelf may cause a strong convergence at the mouth of the ria, which drastically reverses the estuarine circulation.

Two main rivers discharge into this estuary (figure 1): Ulla and Umia, with average flows of 30 and $5 \mathrm{~m}^{3} \cdot \mathrm{s}^{-1}$, respectively, during the period studied. Time evolution of their flows is shown in figure 2a. For both rivers, two periods can be distinguished: "wet" period (from the beginning to the end of July, julian 212) and "dry" period (to the end of october, julian 303). Exchange with the open ocean occurs through two mouths, delimited by Salvora island, the northern one being very shallow (10 m).

In this Ría, an intensive sampling (twice a week) was carried out in summer 1989, in order to quantify the cycles of biogenic elements, relating them to both physical and also biological conditions. Among the former there are upwelling, mixing and circulation, and among the latter the high primary production (about $1 \mathrm{gC} \cdot \mathrm{m}^{-2} \cdot \mathrm{day}^{-1}$ in summer, Prego, 1990, Rosón, 1992) and also the intensive production of mussels that this ria supports (about 100,000 $\mathrm{Tm}$ in 2396 rafts in 1989). 
The first step for describing the role of such biogeochemical budgets which take place in an estuary like Ria de Arousa is the quantitative knowledge of its residual estuarine circulation, which is the most important agent of net water exchange between rias and coastal shelf (Prego et al., 1989; Prego \& Fraga, 1992). Since direct flux measurements are difficult to obtain, due to observational and economic problems, indirect ways that make use of available hydrographic data are preferable.

The knowledge of the space-time distribution of any conservative property allows to cuantify the circulation and mixing from the advection-diffusion equation, which for the case of salinity takes the following form:

$$
\frac{d S}{d t}=-u \frac{\partial S}{\partial x}-v \frac{\partial S}{\partial y}-w \frac{\partial S}{\partial z}+\frac{\partial}{\partial x}\left[K x \frac{\partial S}{\partial x}\right]+\frac{\partial}{\partial y}\left[K y \frac{\partial S}{\partial y}\right]+\frac{\partial}{\partial z}\left[K z \frac{\partial S}{\partial z}\right]
$$

where $\mathrm{S}$ is the salinity in a volume element; $\mathrm{x}, \mathrm{y}$ and $\mathrm{z}$ are the longitudinal, transversal and vertical coordenates; $u, v, w$, are the respective velocity components (residual estuarine velocities), and $\mathrm{K}_{\mathrm{X}}, \mathrm{K}_{\mathrm{y}}, \mathrm{K}_{\mathrm{Z}}$ are the effective turbulent diffusion coefficients in the three axis. The first three terms in [1] are the convective salt transport, and the three last terms are the mixing salt transport. They all are averaged over a tidal cycle.

On the hypothesis that the heat transferred to each volume is employed only in increasing its internal energy, this equation can also be formulated for the other conservative variable: the temperature, given that the ria is in thermal equilibrium (Otto, 1975, Rosón, 1992). However, when considering temperature, it is necessary to add at the right hand side of [1] the heat exchange across the sea surface-atmosphere interface. This term is denoted by $\mathrm{C}_{\mathrm{Q}}$. An analytical resolution of this equation is impossible, due to the high complexity of the system under study. Thus, numerical solutions should be sought for, based on models that make realistic simplifications of the former equation. In this work, we will employ a box model, in which the former equation is solved for finite elements (called boxes) instead of at each point. Any of the 
observable properties is considered homogeneously distributed inside each box. Variations of these quantities are due only to Interchanges across the various boundaries (Officer,1980). These borders can be real, like the seabed, the seashore, the interface with atmosphere, and the surface of division between outward and inward layers, which practically coincides with the pycnocline in partially mixed estuaries. On the other hand, there also are arbitrary borders, like the walls of each box, placed between capes at opposite sides of the ria, where transversal currents are presumably small.

Therefore, the aim of this work is to evaluate the residual estuarine fluxes in Ria de Arousa, according to a developed box model, whose main characteristics are: non stationary, saltheat averaged balanced and Coriolis affected. Once the fluxes are obtained, their relationships with processes that occur inside or outside the Ria, such river volume, heat exchange between airsea interface and upwelling, are investigated.

\section{Material}

From May to October 1989, during the GALICIA X cruise, ten stations in Ría of Arousa (figure 1) were sampled on 46 ocassions twice a week. Seven of them are placed along the principal axis of the ria. Every station was always sampled at the same tidal cycle, and occupied at 5 to 7 depths, depending on bathymetry, using Nisking bottles. Salinity was determined using an Autosal 8400 A and the equation proposed by UNESCO (1983). Temperature was measured with Watanabe inversion termometers. Rivers Ulla and Deza volumes (figure 2a) were quantified by the gauging stations at the mouth of Ulla major tributary, River Deza, and at Caldas de Reyes respectively, according to Rosón et al. (1991). Evaporation was estimated according to appendix 1. Heat exchange with atmosphere (figure 2b) was evaluated by means of appendix 2. Water flow upwelled per kilometer of coast (Finisterre Marine Upwelling, Fraga, 1981) was evaluated from wind data at the Cape Finisterre Meteorological Observatory, according to Wooster et al. (1976). Mean daily upwelling index for the studied period are represented in figure 2c. Negative values

indicate downwelling. Rainfall data were obtained from the Meteorological Observatory at 
Villagarcía de Arousa. Other meteorological data (humidity, air temperature, wind velocity, atmospheric pressure, cloudiness) were taken in situ on board.

\section{Method}

During summer period, Ria de Arousa is an estuary where the density gradient is mainly determined by temperature rather than by salinity. In fact, during the whole studied period, the temperature range in the whole water column was between $20.8^{\circ} \mathrm{C}$ (at surface of the shallowest station, 1 , during high irradiance periods, August $21^{\mathrm{st}}$ ) and $12.2^{\circ} \mathrm{C}$ (in the bottom of station 7 during strong upwelling events, 15th June). Meanwhile, the salinity range varies from 32.2 (at surface of the closest river station 1, during the highest continental runoff, sampling 6 , June $12^{\text {nd }}$ ) to 35.82 (also in the bottom of station 7). The usual salinity and temperature ranges are about 0.6 PSU and $6^{\circ} \mathrm{C}$ respectively, being the averages 35.5 and $15^{\circ} \mathrm{C}$. Thus, the variations that these gradients cause in situ density anomaly are -0.22 and 0.77 respectively. With these values, more than $75 \%$ of the variability in density is caused by temperature.

With this situation, an only-salt-balance box model would not forecast the estuarine circulation fluxes with enough accuracy. It is necessary to introduce the property with highest variability in the estuary, i.e. temperature, through the heat balance. This consideration has been made previously by Rahm and Wulff (1992) to calculate estuarine fluxes in the Baltic Sea.

Ria de Arousa was divided in seven boxes (figure 1) in such a way that each wall contains at least one sampling station. Exchange between boxes 3 and 8 is negligible, due to the shallowness of the boundary ( $2 \mathrm{~m}$ at high tide). Convective-diffusive exchanges that take place in the salt and heat balances of each box are represented in figure 3. A linear algebraic system of equations is set up for each thermohaline property and for each box. Entries to this system are the geometry of the estuary, continental flow (Rosón et al., 1991), evaporation-rainfall balance (appendix 1), and the space-time distribution of both thermohaline properties. Boundary conditions are heat exchange with atmosphere (appendix 2), and river-rainfall salinity (suposed 
null) and temperature. The flux scheme for the calculation of residual fluxes is shown in diagram 1.

Determination of the zero horizontal velocity depth is based on salinity-temperature wallwide averages. It is very close to the depth of the picnocline, where mixing is inhibited. Other authors place it at the halocline (Pritchard, 1951; González et al., 1979; Prego and Fraga, 1991; Rios, 1992) or at the thermocline (Otto, 1975). In this paper, a weigh averaging between both depths is made, since fluxes are also weighed between both properties. The averaged properties over each wall $(\mathrm{N})$ are given by:

$\mathrm{N}=\frac{\int_{0}^{\mathrm{z}} \mathrm{N}(\mathrm{z}) \mathrm{y}(\mathrm{z}) \mathrm{dz}}{\int_{0}^{\mathrm{z}} \mathrm{ydz}} \quad(\mathrm{N}=\mathrm{S}, \mathrm{T})$

The average (over the period studied) of the salinity-temperature calculated zero horizontal residual velocity depth, for wall 7 ( $20 \pm 5 \mathrm{~m})$, is always deeper than the bottom at station $10(12 \mathrm{~m})$, so, in the model, the northern mouth is considered as part of the surface outgoing current of the southern mouth. For a given day, this depth increases shelfward. Once computed the zero horizontal velocity depth $\left(\mathrm{z}_{\mathrm{C}}\right)$, averaged properties in upper $\left(\mathrm{N}_{\mathrm{j}}\right)$ and lower $\left(\mathrm{N}_{0 j}\right)$ layers are calculated according to [2]. The integration extends from the surface to $\mathrm{z}_{\mathrm{C}}$ for $\mathrm{N}_{\mathrm{Xj}}$, and from $\mathrm{z}_{\mathrm{C}}$ to the bottom for $\mathrm{N}_{\mathrm{X} 0 \mathrm{j}}$.

\section{Equations}

In the Ría of Arousa, since low longitudinal gradient of salinity and temperature occurs, diffusive transport along $\mathrm{x}$ axis $\left(\mathrm{Q}_{\mathrm{Mxj}}\right.$ and $\mathrm{Q}_{\mathrm{Mx} 0 \mathrm{j}}$ terms, figure 3) is practically negligible in comparison with convective transport $\left(\mathrm{Q}_{\mathrm{xj}}\right.$ and $\mathrm{Q}_{\mathrm{x} 0 \mathrm{j}}$ terms). In a rough estimate, although mixing fluxes were equal to convective fluxes -this situation would only be created by an unreasonably 
high value of $\mathrm{K}_{\mathrm{X}}$, about $100 \mathrm{~m}^{2} \cdot \mathrm{s}^{-1}$-, salt transport by convection would be three orders of magnitude larger than that due to diffusion (about $150 \mathrm{~g} \cdot \mathrm{s}^{-1}$, Alvarez-Salgado, 1993). In any case, any error over ingoing fluxes is compensated for by the opposite error in outgoing fluxes. Besides, ordinary values of $K_{X}$ in Ria de Arousa are very low (about $10 \mathrm{~m}^{2} \cdot \mathrm{s}^{-1}$, Otto, 1975). Thus, the global volume and salt/heat balances in box j (figure 3) are:

$-\mathrm{Q}_{\mathrm{Xj}} \mathrm{N}_{-} \mathrm{Q}_{\mathrm{X} 0 \mathrm{i}} \mathrm{N}_{+} \mathrm{Q}_{\mathrm{Xi}} \mathrm{N}_{+} \mathrm{Q}_{\mathrm{X} 0 \mathrm{j}} \mathrm{N}_{+\mathrm{L}-\mathrm{E}+\mathrm{R}=0}$

$-Q_{x j}{ }^{N} \cdot N_{j}-Q_{X 0 i} \cdot{ }^{N} \cdot N_{0 i}+Q_{x i}{ }^{N} \cdot N_{i}+Q_{x 0 j}{ }^{N} \cdot N_{0 j}+L_{L}+R N_{R}+C_{Q}=\left(V j+V_{0 j}\right) \cdot(d N / d t)$

$\mathrm{i}=1$ to 6 and $8 ; \mathrm{j}=2$ to $7 . \mathrm{N}=\mathrm{S}$ or $\mathrm{T}$.

Where $\mathrm{V}_{\mathrm{j}}+\mathrm{V}_{0 \mathrm{j}}$ is the mean tidal volume of box $\mathrm{j} \cdot \mathrm{Q}_{\mathrm{xi}}{ }^{\mathrm{N}}$ and $\mathrm{Q}_{\mathrm{x} 0 \mathrm{i}}{ }^{\mathrm{N}}$ are known by means of a former similar balance in box $\mathrm{i}=\mathrm{j}-1$. Residual convective horizontal fluxes in inner singlelayer boxes 1 and $8\left(\mathrm{Q}_{\mathrm{X} 1} \mathrm{~N}, \mathrm{Q}_{\mathrm{X} 10} \mathrm{~N}, \mathrm{Q}_{\mathrm{X} 8}{ }^{\mathrm{N}}, \mathrm{Q}_{\mathrm{X} 80} \mathrm{~N}\right)$ were previously known by means of a balance involving rivers Ulla and Umia respectively. Equations [3] and [4] lead to two sets of volume and salt/heat balance residual convective horizontal fluxes $\left(\mathrm{Q}_{\mathrm{xj}} \mathrm{S}, \mathrm{Q}_{\mathrm{xj} 0} \mathrm{~S}\right.$ and $\mathrm{Q}_{\mathrm{xj}}{ }^{\mathrm{T}}$, $\mathrm{Q}_{\mathrm{xj} 0}{ }^{\mathrm{T}}$ respectively), weighed as shown in appendix 3 .

Volume balance in the lower layer allows us to calculate vertical convective fluxes $\left(Q_{\mathrm{Zj}} \mathrm{S}\right.$ and $\mathrm{Q}_{\mathrm{zj}}{ }^{\mathrm{T}}$ ):

$\mathrm{Q}_{\mathrm{x} 0 \mathrm{j}} \mathrm{N}_{-\mathrm{Q}_{\mathrm{X} 0 \mathrm{i}}} \mathrm{N}_{-} \mathrm{Q}_{\mathrm{zj}} \mathrm{N}^{\mathrm{N}} \mathrm{dV} \mathrm{V}_{0 \mathrm{j}} / \mathrm{dt}$

Salt/heat balance in the lower layer yields mixing fluxes $\left(\mathrm{Q}_{\mathrm{Mzj}} \mathrm{S}\right.$ and $\left.\mathrm{Q}_{\mathrm{Mzj}}{ }^{\mathrm{T}}\right)$ :

$Q_{x 0 j}{ }^{N} \cdot N_{0 j}-Q_{x 0 i}{ }^{N} \cdot N_{0 i}-Q_{z j}{ }^{N} \cdot N_{z j}+Q_{M z j}{ }^{N} \cdot\left(N_{j}-N_{0 j}\right)=d\left(N_{0 j} \cdot V_{0 j}\right) / d t$

$\mathrm{i}=1$ to 6 and 8 ; $\mathrm{j}=2$ to 7 . $\mathrm{N}=\mathrm{S}$ or $\mathrm{T}$.

Vertical convective and diffusive sets of fluxes are also weighed (see appendix 3) as before. 
Non-Stationary term.

Single (Gonzalez et al., 1979), fortnightly (Rios, 1992) or monthly (Prego, 1989) samplings make necessary the imposition of steady-state condition $(\partial \mathrm{N} / \partial \mathrm{t}=0)$. This hypothesis can only be applied in cases of non wind-forced periods. However, upwelling events bring up colder and saltier subsurface waters into the ría (Fraga, 1981), so $\partial \mathrm{S} / \partial \mathrm{t}>0$ and $\partial \mathrm{T} / \partial \mathrm{t}<0$ (opposite in the case of downwelling) and a non steady-state condition must be assumed. A complete study of biogeochemical processes in the ria requires a more intensive sampling, enough for the biweekly scale of the Iberian coastal upwelling (Blanton et al., 1987, Alvarez-Salgado et al., 1993).

Time variations of thermohaline properties are calculated by difference between a given sampling (n) and the former (n-1) and subsequent $(\mathrm{n}+1)$ samplings. Although the time between two samplings is either 3 or 4 days, equidistant sampling is assumed. 
$\mathrm{d}\left(\mathrm{N}_{0 \mathrm{j}} \cdot \mathrm{V}_{0 \mathrm{j}}\right) / \mathrm{dt}=$

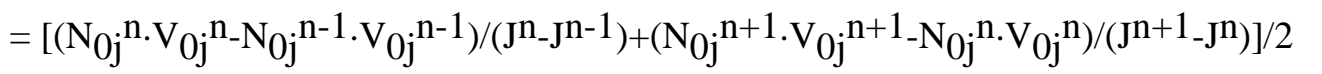

$\mathrm{j}=2$ to $7 . \mathrm{N}=\mathrm{S}$ or $\mathrm{T}$.

The time variation of lower layer volume due to the change in the depth of the pycnocline (and therefore in the zero horizontal velocity depth) with time is also included in equation [5]:

$d V_{0 j} / d t=\left[\left(V_{0 j}{ }^{n}-V_{0 j}{ }^{n-1}\right) /\left(J^{n}-J^{n-1}\right)+\left(V_{0 j}{ }^{n+1}-V_{0 j}{ }^{n}\right) /\left(J^{n+1}-J^{n}\right)\right] / 2$

Velocity of outgoing current at the mouth of the Ria.

The velocity of surface current is supossed to be the same along a given section of the ria. We also assume that velocity of the surface current through walls 10 (northern mouth) and 7 (southern mouth) is the same. Thus, the total outgoing flux can be considered as a unique body of water, with salinity and temperature given by:

$\mathrm{N}_{\mathrm{X} 710}=\left[\mathrm{N}_{\mathrm{X} 10} \cdot \mathrm{A}_{10}+\mathrm{N}_{\mathrm{X} 7} \cdot \mathrm{A}_{7}\right] /\left(\mathrm{A}_{10}+\mathrm{A}_{7}\right) \quad(\mathrm{N}=\mathrm{S}, \mathrm{T})$

where $A_{10}$ and $A_{7}$ are the surface areas of walls 10 and 7 respectively.

Coriolis Effect. Its introduccion in the model.

The stations placed at the middle of the main channel are not enterely representative of the whole width of the estuary, because transversal differences appear due to Coriolis acceleration (Otto, 1975). This effect causes an asymmetry in the horizontal convective velocity field $(u)$ as well as in the density distribution. In fact, this effect has previously been observed in this ria by Gómez Gallego (1971), Otto (1975), and Castillejo \& Lavín (1982), and can also be observed from variation of surface salinity in both mouths of the Ria de Arousa (stations 7 and 10, figure 4). The northern shore is always less saline than the southern one in the whole period studied. The 
transversal variation in salinity distribution can be seen in figures $7 \mathrm{a}$ and $7 \mathrm{~b}$ during normal $\left(\mathrm{J}=191,10^{\text {th }}\right.$ July) and reversal $\left(\mathrm{J}=303,30^{\text {th }}\right.$ October) estuarine circulation respectively. In situations of positive residual circulation, the isohalines are sloped to the southern shore (figure 5a), while during downwelling events, when reversal in estuarine circulation occurs in the ria (see below) the isohalines are sloped to the northern shore (figure 5b). To take into account this consideration in the model, a relationship between upper layer salinities of stations 10 and 7 has been applied to the rest of stations for every day:

$\mathrm{S}_{\mathrm{Xi}}(\mathrm{av})=\mathrm{S}_{\mathrm{Xi}} \cdot \mathrm{S}_{710} / \mathrm{S}_{\mathrm{X} 7} ; \quad$ and $\quad \mathrm{S}_{\mathrm{i}}(\mathrm{av})=\mathrm{S}_{\mathrm{i}} \cdot \mathrm{S}_{710} / \mathrm{S}_{7}$

Modelling the time evolution of fluxes at non-sampling intervals

For giving a time continuity to the model, we can compute the fluxes between two samplings, assuming linear time evolution of thermohaline properties between them. The amount of any thermohaline property $\mathrm{N}$ in each box, and for each sampling $\left(\mathrm{J}^{\mathrm{n}}\right)$ is a function of the previous one $\left(\mathrm{J}^{\mathrm{n}-1}\right)$ through

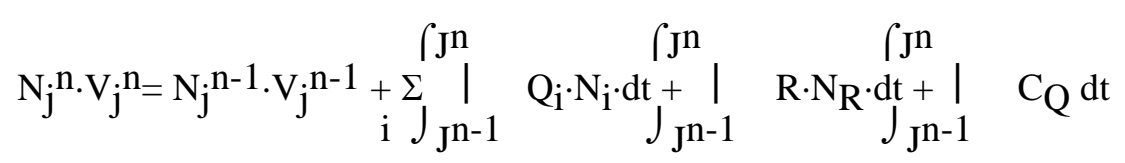

where the sum over $\mathrm{i}$ is extended to every horizontal-vertical and/or convective-diffusive fluxes $\left(\mathrm{Q}_{\mathrm{j}}\right)$. We can assume a linear change in the interface concentrations $\left(\mathrm{N}_{\mathrm{i}}\right)$ with time, and also in the heat exchange $\left(\mathrm{C}_{\mathrm{Q}}\right)$ and river volume $(\mathrm{R})$ between $\mathrm{J}^{\mathrm{n}}$ and $\mathrm{J}^{\mathrm{n}-1}$ samplings. With these assumptions, second and third integrals of [11] are easily computed (appendix 4). However, the time evolution of fluxes $\left(\mathrm{Q}_{\mathrm{i}}\right)$ does not have to be linear, because they are inversely proportional to the gradient of thermohaline properties, that is, the difference $\left(\mathrm{N}_{\mathrm{Xi}}-\mathrm{N}_{\mathrm{X} 0 \mathrm{i}}\right)$ (as can be easily deduced from equation [3] and [4]), which we have assumed that varies linearly with time. 
Since the time variation of fluxes is not linear, we propose that fluxes can be fitted to a second order function, which permits to resolve easily the first integral of the right side of [11]. We can create a parabolic function that passes through $\left.\left[\mathrm{Q}\left(\mathrm{J}^{\mathrm{n}}-1\right), \mathrm{J}^{\mathrm{n}-1}\right] ; \mathrm{Q}\left(\mathrm{J}^{\mathrm{n}}\right), \mathrm{J}^{\mathrm{n}}\right]$ and $\left[\mathrm{Q}_{\mathrm{m}}\right.$, $\left.\mathrm{t}_{\mathrm{m}}=\left(\mathrm{t}_{1}+\mathrm{t}_{2}\right) / 2\right]$; being $\mathrm{Q}\left(\mathrm{J}^{\mathrm{n}}\right)$ and $\mathrm{Q}\left(\mathrm{J}^{\mathrm{n}-1}\right)$ the fluxes for a given and previous sampling respectively (both already known from eqs. [3] to [6]), and $\mathrm{Q}_{\mathrm{m}}$ the flux for the intermediate day (see appendix 4). $\mathrm{Q}_{\mathrm{m}}$ is the unique unknown of equation [11]. The integrals in [11] can be computed by means of appendix 4, and fluxes for the intermediate day, $\mathrm{Q}_{\mathrm{m}}$ can be known. These fluxes are weighed again as shown in appendix 3. In this way, we compute 90 fluxes, which satisfy the time continuity in the distribution of salinity and temperature, in each box, over the whole period.

\section{Results and discussion}

By means of the kinematic bidimensional model described above and its application to the Ria de Arousa, the horizontally integrated velocity field ( $u$ and $w$ respectively), as well as vertical turbulent diffusion coefficients between upper and lower levels $\left(\mathrm{K}_{\mathrm{Z}}\right)$, are derived from the spacetime distribution of thermohaline properties.

By introducing $\mathrm{Q}\left(\mathrm{J}^{\mathrm{n}}-1\right), \mathrm{Q}_{\mathrm{m}}$ and $\mathrm{Q}\left(\mathrm{J}^{\mathrm{n}}\right)$ in equation [11], we can estimate the distribution of salinity and temperature for a certain sampling $\left(\mathrm{N}_{\mathrm{j}}^{\mathrm{n}}\right)$ from that in the previous one $\left(\mathrm{N}_{\mathrm{j}}^{\mathrm{n}-1}\right)$. In order to check the model, we can compare the real distributions with those calculated from the model, i.e. the degree of agreement between the estimated and experimental salinity and temperature values. For the values of each box (i.e. for $u$ ), the model fits between 82 and $97 \%$ of variance. Figure 6 shows the error distribution (real minus predicted) on both thermohaline properties for the most representative station (E4). When the values of the fluxes computed by salinity $\left(Q_{x j}{ }^{S}\right.$, appendix 3) and temperature $\left(Q_{x j}{ }^{T}\right)$ are very close, the deviations become nearly cero. However, when they are different, the deviations are high. In this case, the error function $\Phi$ (proposed in appendix 3) averages the imbalance of both fluxes, and therefore both errors are distributed in the same way. 
In the upper level (i.e. for $w$ and $\mathrm{K}_{\mathrm{Z}}$ ), the agreement falls to $70 \%$ in average. This fact is mainly due to the error associated to vertical diffusion fluxes, which should be used cautiously.

Horizontal and vertical convective fluxes

Time evolutions of horizontal convective residual fluxes for 4 lower wall is represented in figure 7a. As station 4 is the most representative for the whole ria (Rosón et al, 1994), the rest of fluxes are closely related with those. The weakest correlations between each flux versus E4 correspond to the inner stations, $1(44 \%)$ and $8(4 \%))$. In the main channel, the mean correlation is high (77\%), and a progressive increase of fluxes is observed from $20 \%$ (wall 1) to $220 \%$ (wall 7) of that at wall 4 . These ratios are of the same order than those between areas of the walls, so $u$ is similar in all the stations placed at the main channel, with average values between 2 and 4 $\mathrm{km} \cdot \mathrm{day}^{-1}$.

Residual fluxes are of the same order as those calculated by stationary salt balance-box models in summer by Otto (1975) and also by González et al. (1979) in September and November. In the same way, the averaged horizontal residual velocity at station $4\left(3.4 \mathrm{~km} \cdot \mathrm{day}^{-1}\right)$ is very similar to those registered by current meters at the same place in April (Castillejo and Lavín, 1982).

The structure of the water column can be caused by meteorologically induced processes that occur in the shelf, such as upwelling. This fact has already been pointed out by Chase (1975), Gomez Gallego (1975) and Otto (1975) for the Ria de Arousa. Other processes that occur inside the ría can modify this structure, such as river volume or heat exchange with atmosphere (Otto, 1975). To quantify the importance of these three factors, a multivariable correlation analysis with lower horizontal residual convective fluxes $\left(\mathrm{Q}_{\mathrm{X} 0 \mathrm{j}}\right)$ has been performed:

$\mathrm{Q}_{\mathrm{X} 0 \mathrm{j}}=\mathrm{a}_{1}+\mathrm{a}_{2} \cdot \mathrm{I}_{\mathrm{W}}>+\mathrm{a}_{3} \cdot \mathrm{C}_{\mathrm{Q}}+\mathrm{a}_{4} \cdot \mathrm{R}$ 
In this analysis, a mean upwelling index $\left(<\mathrm{I}_{\mathrm{W}}>\right)$ was calculated from the average upwelling index of the same day and the two days before.

$<\mathrm{I}_{\mathrm{W}}>=1 / 3 \cdot\left[\mathrm{I}_{\mathrm{WJ}}+\mathrm{I}_{\mathrm{WJ}-1}+\mathrm{I}_{\mathrm{WJ}-2}\right]$

Upwelling is the major factor of the circulation in the estuary, because it forces the entry of water across the lower level. It accounts for an average of $28 \%$ of variability found from estimated flux in the ría, and $50 \%$ at wall 4 . Thus, at wall 4 , fluxes can be estimated by means of the empiric relationship:

$\mathrm{Q}_{\mathrm{X} 04}=(2.5 \pm 0.2 \mathrm{~km}) \cdot<\mathrm{I}_{\mathrm{W}}>\quad\left(\mathrm{n}=90, \mathrm{r}^{2}=0.50\right)$

where the intercept has not been given due to its poor significance, but it is slightly positive. Thus, residual estuarine flux exists in absence of upwelling. Time variation of $\mathrm{Q}_{\mathrm{x} 04}$ (figure $7 \mathrm{a}$ ) agrees with the graph of time variation of $\mathrm{I}_{\mathrm{W}}$. It is not usual that wind over the shelf is the responsible of half of the hydrodynamic variability found in an estuary (Wroblesky and Hofman, 1989). It is because of this fact that Ria de Arousa is a specialy favourable place for the developement of planktonic community (Figueiras and Pazos, 1991) and the organisms that depend on it, specially mussels (Blanton et al, 1987).

An average of $9 \%$ and $5 \%$ of the remaining variability is explained by the heat exchange with atmosphere and continental runoff respectively. Thus, the river and the heat exchange with atmosphere do not act as forcing agents, but just as tracers.

Taking into account the width at the mouth of the ria (M), from the coefficient of equation [13], we can define the upwelling attenuation rate, $\alpha$ (dimensionless) as:

$\alpha=100 \cdot \mathrm{Q}_{\mathrm{Xj}} /\left(<\mathrm{I}_{\mathrm{W}}>\cdot \mathrm{M}\right)$ 
Where $\mathrm{Q}_{\mathrm{xj}}$ is the flux estimated by box model, $<\mathrm{I}_{\mathrm{W}}>$ is the Ekman transport along the width of each wall, and $M=5.5 \mathrm{Km}$ wide. $\alpha$ varies from $5 \%$ at the inner-most station (1), where the influence of the water mass transport is not apparent, to practically $100 \%$ at the outer station (7), where coastal upwelling acts directly. At station 4 its value is half of that at the mouth.

During the most intense upwelling event over the period studied, (at the beginning of September, peak at $\mathrm{J}=247$, average $\mathrm{I}_{\mathrm{W}}=2000 \mathrm{~m}^{3} \cdot \mathrm{s}^{-1} \mathrm{Km}^{-1}$ ) the wind that blows over the shelf clearly dominates the circulation inside almost the whole ria. In this period, the residual water exchange between ria and shelf $\left(5035 \mathrm{~m}^{3} \cdot \mathrm{s}^{-1}\right.$ and $9.5 \mathrm{~cm} \cdot \mathrm{s}^{-1}$ at station 4 , and $16136 \mathrm{~m}^{3} \cdot \mathrm{s}^{-1}$ or $14.8 \mathrm{~cm} \cdot \mathrm{s}^{-1}$ at station 7 ) is nearly comparable (55\% and 76\% respectively) with the exchange caused by the tidal wave.

At the end of the studied period, with predominant southerly winds, a convergence occurs and piling up of water at the mouth of the ria takes place. A strong downwelling event occurs (average upwelling index $-2000 \mathrm{~m}^{3} \mathrm{~s}^{-1} \mathrm{~km}^{-1}$ ), that causes a surface water transport towards the coast, and an strong inverse estuarine circulation takes place in the ría, the fluxes being highly negative (less than $-12000 \mathrm{~m}^{3} \cdot \mathrm{s}^{-1}$ or $-20.5 \mathrm{~cm} \cdot \mathrm{s}^{-1}$ at station 4 , and $-26000 \mathrm{~m}^{3} \cdot \mathrm{s}^{-1}$ or $-21.9 \mathrm{~cm} \cdot \mathrm{s}^{-1}$ at station 7, both the least of the whole period). The intensity of this event was so high, that even in the inner part of the ria circulation was strongly inverted $\left(-1612 \mathrm{~m}^{3} \cdot \mathrm{s}^{-1}\right.$ or $-10.2 \mathrm{~cm} \cdot \mathrm{s}^{-1}$ at station 1 and $-1934 \mathrm{~m}^{3} \cdot \mathrm{s}^{-1}$ at station 8). During this period, the strong vertical mixing and therefore the absence of a marked halocline in the outer ria would make impossible the calculation of residual fluxes by previous box model methods in this area. Instead, the use of the heat balance in this model allows a realistic resolution of fluxes.

With the final downwelling situation, a clear decoupling between circulation in the inner and outer ria is observed. In the inner ria, a positive circulation may occur, because this area is far from the influence of the convergence. Meanwhile, in the outer ria, a reversal in estuarine circulation takes place (see figure 7a). Station 4 is placed on the border of this change of behaviour. 
A strong coupling between convective horizontal and vertical fluxes is observed (figures $7 \mathrm{a}$ and $7 \mathrm{~b})$. Thus, at station 4 , an average of $68 \%$ of volume that enters across the lower level of wall 4 is raised up to the upper lever, and only $32 \%$ is advected to box 3 . Thus, upwelling is also the main factor responsible for the variability in $\mathrm{Q}_{\mathrm{zj}}$. This fact is mainly due to the abrupt change of bathymetry that occurs at station 4 (figure 1 ).

\section{Flushing times}

Equation [13] is also useful to estimate the flushing times in Ria de Arousa, from upwelling index or wind over shelf data by means of the following equation:

$t_{j}=\left|\left(V_{j}+V_{0 j}\right) /\left(R+L+Q_{x i}+Q_{x 0 j}\right)\right|$

where vertical bars were added to include the case of negative fluxes. For the whole ría an average fluxing time of 9 days during the whole period was found. Figure 8 shows the inverse of the averaged residence times in box $4\left(1 / t_{4}\right.$ values, in day $\left.{ }^{-1}\right)$ for the 45 periods, versus upwelling index. The shortest flushing times (less than two days) coincide with periods of strong divergence ( $\mathrm{J}=247,4^{\text {th }}$ September) or convergence $\left(\mathrm{J}=292,19^{\text {th }}\right.$ October), while periods with the longest renewal times correspond to weak or nearly zero upwelling. This process causes a slowing down motion of the exchange ria-shelf $\left(\mathrm{J}=205,24^{\text {th }}\right.$ July). The situation of no residual circulation, if maintained during several days, may cause a massive proliferation of red tide organisms in the estuary (Fraga and Prego, 1989). However, this situation did not occur because northernly winds over shelf were rapidly re-established.

\section{Vertical diffusive fluxes}

The degree of mixing is the result of the balance between the external causes that have a tendency towards keeping the system stratified in any of thermohaline properties (mainly river 
and insolation) and the phenomena that tend to its homogeneisation (up- or downwelling). Time evolution of vertical diffusive residual fluxes for wall 4 is represented in figure 7c. In situations where strong water runoff (samplings 1 to 20) and/or heat from atmosphere cause stability in the water column, the weaker vertical diffusive fluxes are found (even in upwelling situations), because a marked pycnocline is established, which acts as a physical barrier between both layers.

During a moderate upwelling event, the pycnocline rises up and gets thiner itself. With a high stratification situation, mixing is not favoured $\left(7,36\right.$ and $719 \mathrm{~m}^{3} \cdot \mathrm{s}^{-1}, \mathrm{~J}=198,17^{\text {th }} \mathrm{July}$, at boxes 2, 4 and 7 respectively), while during upwelling relaxation the oppossite situation occurs, yielding moderate values (495, 183 and $6276 \mathrm{~m}^{3} \cdot \mathrm{s}^{-1} \mathrm{~J}=219$, 17th July). Nevertheless, if the upwelling is strong (sampling 30), that structure may break up, giving high values of vertical mixing (1211, 1361 and $11002 \mathrm{~m}^{3} \cdot \mathrm{s}^{-1}, \mathrm{~J}=247$, 4th September). During the final strong downwelling event (samplings 34 and 42 to 46), a reversal in estuarine circulation occurs and the high turbulence also causes the pycnocline to be broken. Thus, high values of vertical diffussion coefficients are found (1040, 2249 and $12779 \mathrm{~m}^{3} \cdot \mathrm{s}^{-1} \mathrm{~J}=261,18^{\text {th }}$ September and 1911, 1386 and $7937 \mathrm{~m}^{3} \cdot \mathrm{s}^{-1} \mathrm{~J}=297,24^{\text {th }}$ October).

Tide-River flows Ratio. A re-definition.

The importance of residual currents with regard to tidal currents in the estuarine circulation is mainly controlled by river and tidal flows. The ratio $(L=\mathrm{P} / \mathrm{R})$ between the tidal prism (P) and the river volume that outflows to the ria during a tidal cycle (R) is useful as a rough index of the estuarine circulation pattern. For $L>100$ we are in a estuary of type 3 (Bowden, 1980) or B (Pritchard, 1955; Beer, 1983), that is, a partially stratified estuary, with strong vertical mixing and two layer horizontal circulation. However, if $L>1000$, it is nearly a vertically homogeneus estuary, types 1 (Bowden, 1980) or C and D (Pritchard, 1955) where the circulation is mainly dominated by the tide and flushing times for the bodies of water are short (Cameron \& Pritchard, 1963; Morris, 1985). 
During the whole period, all the stations have values of $L$ in one of the two types described above. A clear tendency to increase shelfward is noted (mean values: 200 in E1, 900 in E4 and 2000 in E7), because the freshwater is diluted in the body water. At station 4, the large time variability (figure 9) is due to both the erratic continental runoff (figure 2a) and to the high differences of tidal amplitudes (between 1.05 and 3.75 m, Alvarez-Salgado, 1993), that cause a rise in vertical mixing (Dyer, 1991).

However, the use of $L$ implies the consideration that the river is the forcing agent of the two layered estuarine circulation. Therefore, the validity of index $L$ for establishing the type of circulation is limited by the upwelling, the continental runoff being a mere dilutant. Thus, we propose the modified index:

$L^{\prime}=\mathrm{P} /(\mathrm{R}+\mathrm{I})$

Where $\mathrm{I}$ is the upwelled water volume during a tidal cycle i.e. $\mathrm{I}=\alpha \cdot \mathrm{I}_{\mathrm{w}} \cdot \mathrm{M} . \alpha$ is the upwelling attenuation rate, defined above (eq. [14]); $\mathrm{M}$ is the width at the mouth of the ria (5.5 km).

Therefore, taking the averages $\mathrm{R}=30 \mathrm{~m}^{3} \cdot \mathrm{s}^{-1}$ and Iw $=380 \mathrm{~m}^{3} \cdot \mathrm{s}^{-1} \cdot \mathrm{Km}^{-1}$, for the mouth of the ria $(\alpha \approx 1)$, we have $\mathrm{R}+\mathrm{I} \approx 70 \cdot \mathrm{R}$ and $L^{\prime} \approx 14$. By means of this new definition, $L^{\prime}$ values are close to those proposed for partially stratified estuaries, even when river volume is low. Figure 9 also shows the time evolution of $L^{\prime}$ index (in logarithmic scale) in station 4. It also shows large time variation mainly due to the biweekly periodicity of upwelling events (Alvarez-Salgado et al, 1993).

\section{Conclusions}

Several improvements have been made in this kinematic model with regard to the previous box models. Firstly, it introduces not only the salt but also the thermal energy balance in each volume element (equation [7]). Secondly, it takes into account the time evolution of thermohaline 
properties (non stationary terms). Besides, it computes the changes in the level of pycnocline by means of time evolution of lower level volume (equation [8]). Coriolis effect causes transversal variation of salinity in each section of the ria. The model also corrects this differences by means of equation [10]. Therefore, it can be considered as a $2 \frac{1}{2} \mathrm{D}$ model. The introduction of intermediate-day fluxes (appendix 4), gives more time continuity to the model and permits it to describe a realistic circulation at not-sampling intervals. Finally, the establishment of the weighaveraged estuarine fluxes is made (appendix 3), in order to take into account both thermohaline properties in the calculation of fluxes.

Therefore, the proposed box model is more realistic than the previous ones. In fact, it solves situations in which weak haline gradients appear in the ria, caused both because of the absence of continental runoff, and/or water surface transport towards/from the shelf (up/downwelling situations respectively).

The internal dynamics of the Ria de Arousa in summer is mostly controlled by the exchange with the shelf, induced by the wind, rather than by the interaction with the other two boundaries of the system: continental runoff and heat exchange with the atmosphere. During upwelling situations, the ria behaves as a positive estuary, while with southerly wind, the opposite behaviour occurs (reversal estuarine circulation).

The knowledge of the physical circulation in Ria de Arousa allows us to foresee the distribution of any conservative property inside the estuary. This study is the first step towards a more complete model based on the biogeochemical circulation in Ria de Arousa, that intends to evaluate the budgets of the non conservative properties in the boxes into which the estuary was divided. By means of those budgets, it will be possible to estimate the amounts of biogeochemical elements $(\mathrm{C}, \mathrm{N}, \mathrm{P}, \mathrm{Si})$ that are exchanged in relation to processes other than specifically hydrodynamic, i.e. that involve the photosyntesis-mineralisation cycle, mainly carried out by the phytoplankton. The salt balance of each element inside each box will allows us to estimate the consumption or generation of a certain property in this volume. 


\section{Aknowledgements.}

We thank all participants in GALICIA X cruise and all the crews of R/Vs Investigador-S and Explorador, and also Luis Fariña for his comments and for correcting the manuscript. This work was supported by the grant MAR88-0245 of the Comision Interministerial de Ciencia y Tecnología (CICYT), and resources from the Consellería de Pesca de la Xunta de Galicia. 


\section{Figure captions}

Figure 1: Map of Ría de Arousa, showing the sampling stations (squares), and the segmentation made to subdivide it in eight boxes, by a series of cross sections (walls). Dotted lines show the bathymetry.

Figure 2: Mean daily time variation of a) flow of the two main rivers those discharge in Ria de Arousa. b) heat exchange between air-sea interface $\left(\mathrm{C}_{\mathrm{Q}}\right.$ term) calculated according to appendix 2, and c) Finisterre Upwelling Index $\left(\mathrm{I}_{\mathrm{W}}\right)$ for the studied period.

Figure 3: Diagram of convective-diffusive terms that take place in the salt-heat balances of each box. $\mathrm{N}$ is the considered property ( $\mathrm{N}=\mathrm{S}$ for salt balance; $\mathrm{N}=\mathrm{T}$ for heat balance). All of these data were used to calculate the fluxes given in equations [3] to [6] inclussive.

$\mathrm{C}_{\mathrm{Q}}$ : Exchange of heat between sea surface and atmosphere (appendix 2).

E: Loss of surface water by evaporation (appendix 1).

R: Flow of Rivers Ulla and Umia runoff.

$\mathrm{N}_{\mathrm{R}}$ : Concentration of property $\mathrm{N}$ in the river flow. $\mathrm{S}_{\mathrm{R}}=0$ was taken.

L: Rainfall.

$\mathrm{N}_{\mathrm{L}}$ : Concentration of property $\mathrm{N}$ in the rainfall. $\mathrm{S}_{\mathrm{L}}=0$ and $\mathrm{t}_{\mathrm{L}}=\mathrm{t}_{\text {air }}$ were taken.

$\mathrm{Q}_{\mathrm{Xi}}$ : Horizontal convective residual flux that passes across upper layer of wall $\mathrm{i}$.

$\mathrm{Q}_{\mathrm{Mxi}}$ : Horizontal diffusive flux that passes across upper layer of wall $\mathrm{i}$.

$\mathrm{N}_{\mathrm{Xi}}$ : Averaged concentration of property $\mathrm{N}$ in the upper layer of wall $\mathrm{i}$.

$\mathrm{Q}_{\mathrm{X} 0 \mathrm{i}}$ : Horizontal convective residual flux that passes across lower layer of wall $\mathrm{i}$.

$\mathrm{Q}_{\mathrm{Mx} 0 \mathrm{i}}$ : Horizontal diffusive flux that passes across lower layer of wall $\mathrm{i}$.

$\mathrm{N}_{\mathrm{X} 0 \mathrm{i}}$ : Averaged concentration of property $\mathrm{N}$ in the lower layer of wall $\mathrm{i}$.

$\mathrm{Q}_{\mathrm{xj}}$ : Horizontal convective residual flux that passes across upper layer of wall $\mathrm{j}$.

$\mathrm{Q}_{\mathrm{Mxj}}$ : Horizontal diffusive flux that passes across upper layer of wall $\mathrm{j}$.

$\mathrm{N}_{\mathrm{xj}}$ : Averaged concentration of property $\mathrm{N}$ in the upper layer of wall $\mathrm{j}$.

$\mathrm{Q}_{\mathrm{X} 0 \mathrm{j}}$ : Horizontal convective residual flux that passes across lower layer of wall $\mathrm{j}$.

$\mathrm{Q}_{\mathrm{Mx} 0 \mathrm{j}}$ : Horizontal diffusive flux that passes across lower layer of wall $\mathrm{j}$.

$\mathrm{N}_{\mathrm{X} 0 \mathrm{j}}$ : Averaged concentration of property $\mathrm{N}$ in the lower layer of wall $\mathrm{j}$.

$\mathrm{Q}_{\mathrm{zj}}$ : Vertical convective flux that passes across the interface between both layers.

$\mathrm{Q}_{\mathrm{Mzj}}$ :Vertical diffusive flux that passes across the interface between both layers.

$\mathrm{N}_{\mathrm{j}}$ : Averaged concentration of property $\mathrm{N}$ in the upper layer of box $\mathrm{j}$.

$\mathrm{N}_{0 \mathrm{j}}$ : Averaged concentration of property $\mathrm{N}$ in the lower layer of box $\mathrm{j}$.

$\mathrm{Vj}$ : Volume of the upper layer.

V0j: Volume of the lower layer

Figure 4. Flux scheme for the calculation of residual estuarine fluxes proposed in this paper.

Figure 5: Time evolution of the averaged layer surface salinity in walls 7 (crosses) and 10 (squares) during the studied period.

Figure 6a: Spatial distribution of salinity from Umia River to northern mouth of Ria de Arousa with normal estuarine circulation ( $\mathrm{J}=191,10^{\text {th }} \mathrm{July}$ ). Sampling points are also shown. 
Figure 6b: Spatial distribution of salinity from Umia River to northern mouth of Ria de Arousa with reversal estuarine circulation ( $\mathrm{J}=303,30^{\text {th }}$ October).

Figure 7: Time distribution of salinity (squares) and temperature (triangles) residuals (observed minus calculated with model, see text) at station 4 .

Figure 8: Time evolution of a) lower layer horizontal convective residual fluxes through wall 4 $\left(\mathrm{Q}_{\mathrm{x} 04}\right)$ and mean upwelling index. b) vertical convective residual fluxes in box $4\left(\mathrm{Q}_{\mathrm{Z} 4}\right)$; and c) vertical diffusive fluxes across the interface between upper and lower layer of box 4 $\left(\mathrm{Q}_{\mathrm{Mz}}\right)$.

Figure 9: Correlation between inverse residence times calculated from horizontal residual fluxes at station 4 and upwelling index, showing positive and reversal estuarine circulation patterns.

Figure 10. Time variability of indices $L$ and $L^{\prime}$ at station 4 (dimensionless, see text) in logarithmic scale. 


\section{References:}

Alvarez-Salgado, X.A. 1993 Mecanismos de transporte y balance biogeoquímico del nitrógeno en la Ría de Arousa. Ph. D. Thesis. University of Santiago de Compostela.

Alvarez-Salgado, X.A., Rosón, G., Pérez, F.F and Y. Pazos 1993 Hydrographic variability off the Rias Baixas (NW Spain) during the upwelling season. Journal of Geophysical Research, 98 (C8), 14.447-14.455.

Beer, T. 1983 Enviromental Oceanography. Oxford, Pergamon Press. 262 pp.

Blanton, J.O., Tenore K.R., Castillejo F., Atkinson L.P. and Lavín, A. 1987 The relationship of upwelling to mussel production in the rias on the western coast of Spain. J. marine research, 45, 497-511.

Bowden, K. F. 1980 Physical factors: salinity, temperature, circulation and mixing processes. In Chemistry and Biogeochemistry of Estuaries (Olausson, E. \& Cato, I. eds.). Chichester: John Wiley and Sons, pp. 37-70.

Cameron, W \& Pritchard, D.W. 1963 Estuaries. In The Sea (Hill, M.N. Ed.) John Wiley \& Sons, Vol 2. pp 306-324.

Castillejo, F.F and Lavín, A. 1982 Contribución al estudio del agua entrante y saliente en la Ría de Arosa. Boletín del Instituto Español de Oceanografía, 7(2), 163-180.

Chase, J. 1975 Wind driven circulation in a spanish estuary. Estuarine and Coastal Marine Science, 3, 303-310.

Dyer, K.R. 1973 Estuaries, a physical introduction. New York: John Wiley and Sons, 140 pp.

Dyer, K.R. 1991 Circulation and mixing in stratified estuaries. Marine Chemistry, 32, 111-120.

Elliott, A.J. 1976a. Methods for determinating the concentrations and sources of pollutants in estuaries.Ches. Bay. Inst. Spec. Rept., 42. 1-40.

Elliott, A.J. 1976b. Estimates of advection and diffussion in the Potomac Estuary. J. Environ. Sci. Health., 2, 131-143.

Figueiras, G. and Y. Pazos. 1991. Microplankton assemblages in three Rías Baixas (Vigo, Arosa and Muros, Spain) with a subsurface chlorophyl maximun: their relationships to hydrography. Mar. Ecol. Prog. Ser., 76, 219-233. 
Fraga, F, \& Margalef, R. 1979 Las Rías Gallegas. In Estudio y explotación del mar en Galicia. Cursos y congresos, University of Santiago de Compostela, pp. 101-122.

Fraga, F. 1981 Upwelling off Galician coast, Northwest Spain. In: Coastal and Estuarine Sciences 1. Coastal Upwelling. Richands, F.A. (Editor). American Geophysical Union. 176-182.

Fraga, F. \& Prego, R. 1989 Condiciones hidrograficas previas a la purga de mar. Cuadernos del Area de Ciencias mariñas. Seminario de Estudos Galegos, 4, 24-44.

González, N., González, J.J., García, C., \& Cabanas, J.M. 1979 Dinámica de nutrientes en las rías de Arosa y Muros (NW España). Boletín del Instituto Español e Oceanografía, 5, 51-79.

Gomez Gallego, J. 1975 Estudio de las condiciones oceanograficas en la Ria de Arosa en invierno. Boletín del Instituto Español de Oceanografía, 155, 1-53.

Morris, A.W. 1985 Estuarine Chemistry and General Survey Estrategy. In Practical Estuarine Chemisrty. A Handbook. Head, P.C. Ed. Cambridge University Press. pp. 1-60.

Officer, C.B. 1980 Box model revisited. In: Estuarine and wetland processes with enphasis on modeling. Hamilton and MacDonald (Eds.). Plenum., 65-114.

Otto, L. 1975 Oceanography of the Ria de Arosa (NW Spain). Konink. Meteor International Medelingen en Verlan, ${ }^{\circ}$ 96. 210 pp.

Prego, R. 1990 Las sales nutrientes en las rias gallegas. Informes técnicos de Scientia Marina 157, 31 pp.

Prego, R., Fraga, F. \& Rios, A.F. 1990 Water interchange between the Ría de Vigo and the coastal shelf. Scientia Marina 54(1), 95-100.

Prego, R. \& Fraga, F. 1992 A simple model to calculate the residual flows in a spanish Ria. Hydrographic consequences in the ria of vigo. Estuarine, Coastal and shelf Science 34, 603615.

Pritchard, D.W. 1951 The physical hydrography of estuaries and some applications to biological problems. Trans $16^{\text {th }}$ North american Wildlife Conference. Wildlife Management Institute, 368-376.

Pritchard, D.W. 1955 Estuarine Circulation Patterns. Proccedings of American Society of Civil Engineering, 81 (717), 1-11. 
Rahm, L. \& Wulff, F. 1992 Using parallel salinity and temperature profiles for calculations of estuarine fluxes with reference to the Baltic proper. Netherlands Journal of Sea Research, 29 (4), 281-289.

Ríos, A. 1992 El fitoplancton en la Ría de Vigo y sus condiciones ambientales. Ph. D. Thesis. University of Santiago de Compostela. ISBN 84-7191-958-3. 416pp.

Rosón, G., Pérez, F.F., Alvarez-Salgado, X.A., \& Ríos, A.F. 1991 Flujos de los aportes de agua continental a la Ría de Arosa. Scientia Marina 55 (4), 583-589.

Rosón, G. 1992 Flujos y ciclo del carbonato cálcico en la Ría de Arosa. Ph. D. Thesis. University of Santiago de Compostela. ISBN 84-7191-957-5. 485 pp.

Rosón, G., Pérez, F.F., Alvarez-Salgado, X.A., and Figueiras, F.G. 1995 Variation of both thermohaline and chemical properties in an estuarine upwelling ecosystem: Ria de Arousa. I. Time evolution. Estuarine and Coastal Shelf Science ,41, 195-213.

Sverdrup, H.U., Johnson, M.W. \& Fleming, R.H. 1942 The Oceans, their Physics, Chemistry and General Biology. Prentice-Hall Inc. 1087 pp.

UNESCO 1983 Algoritms for computacion of fundamental properties of seawater. UNESCO Technical papers in Marine Science, 44. 53pp.

Wooster, W.S., Bakun, A. \& McLain, D.R. 1976 The seasonal upwelling cycle along the eastern boundary of the North Atlantic. Journal of marine Research; 34, 131-141.

Wroblesky, J.S. and Hofman, E.E. 1989 U.S. Interdisciplinary Modelling Studies of CoastalOffshore Exchange processes: Past and future. Progress in Oceanography, 23, 65-69. 
Appendix 1: On the evaluation of evaporation.

The loss of water of every box surface due to evaporation was estimated on the basis of the empiric relationship (Otto, 1975)

$E=(0.26+0.077 \cdot W) \cdot\left(e_{s}-e_{z}\right)\left(m m \cdot d a y^{-1}\right)$,

where $\mathrm{W}$ is wind velocity in $\mathrm{m} \cdot \mathrm{s}^{-1} ; \mathrm{e}_{\mathrm{S}}$ and $\mathrm{e}_{\mathrm{Z}}$ is the vapour pressure of water at the sea surface and 2 meters over sea surface, respectively, in mbar, which can be calculated as:

$\mathrm{e}_{\mathrm{z}}=\mathrm{e}\left(\mathrm{t}_{\mathrm{air}}\right) \cdot \mathrm{H} / 100(\mathrm{~mm} \mathrm{Hg})$ and $\mathrm{e}_{\mathrm{s}}=\mathrm{e}\left(\mathrm{t}_{\text {sur }}\right) \cdot\left(1-0.000537 \cdot \mathrm{S}_{\text {sur }}\right) \quad(\mathrm{mm} \mathrm{Hg})$

where $\mathrm{H}$ is the humidity of air in $\%, \mathrm{~S}_{\text {sur }}$ is the surface salinity, and $\mathrm{e}(\mathrm{t})$ is the destilled water vapour pressure, which depends on the respective temperature, and can be well fitted from tables between $\mathrm{t}=5$ and $\mathrm{t}=22^{\circ} \mathrm{C}$ by:

$\mathrm{e}(\mathrm{t})=\mathrm{a}_{0}+\mathrm{a}_{1} \cdot \mathrm{t}+\mathrm{a}_{2} \cdot \mathrm{t}^{2}+\mathrm{a}_{3} \cdot \mathrm{t}^{3}+\mathrm{a}_{4} \cdot \mathrm{t}^{4} \quad(\mathrm{~mm})$

where $\mathrm{t}$ is expressed in ${ }^{\circ} \mathrm{C}$ and:

$\mathrm{a}_{0}=4.589 ; \mathrm{a}_{1}=0.330 ; \mathrm{a}_{2}=0.011 ; \mathrm{a}_{3}=1.53 \cdot 10^{-4} ; \mathrm{a}_{4}=3.74 \cdot 10^{-6}$. 
Appendix 2: On the evaluation of heat exchange between sea surface and atmosphere.

Irradiation is evaluated according to Mosby's formula (Sverdrup et al. 1942), fitted for a complete year, for $42^{\circ} \mathrm{N}$ latitude, as function of the cloudiness $\mathrm{N}$ (in eighths of sky coverage) and the julian day $\mathrm{J}$ (starting at $1^{\text {st }}$ January).

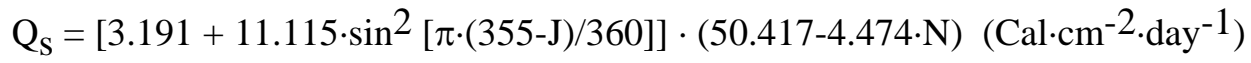

IR back radiation from atmosphere is mainly due to main greenhouse gases $\left(\mathrm{CO}_{2}\right.$ and $\mathrm{H}_{2} \mathrm{O}$ ) quantified from Brunt's ecuation, empirically adapted for the Ría de Arousa and corrected for a cloudy sky by Otto (1975):

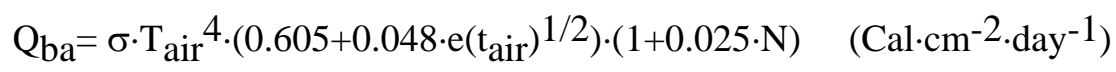

where $\sigma$ is the Stefan-Boltzmann constant $\left(11.7 \cdot 10^{-8} \mathrm{Cal} \cdot \mathrm{cm}^{-2} \cdot \mathrm{day}^{-1} \cdot \mathrm{K}^{-1}\right), \mathrm{T}_{\text {air }}$ is the air temperature in Kelvin, $\mathrm{e}\left(\mathrm{t}_{\mathrm{air}}\right)$ is the water vapour pressure at air temperature in mbar (see appendix 1). $\mathrm{N}$ is the cloudiness (in eighths of sky coverage).

Exchange of heat by conduction can be evaluated by the following empiric ecuation (Otto, 1975), which depends on the temperature difference between sea surface and atmosphere.

$\mathrm{Q}_{\mathrm{h}}=24.88(0.38+0.114 \cdot \mathrm{W})\left(\mathrm{t}_{\mathrm{sur}}-\mathrm{t}_{\text {air }}\right) \quad\left(\mathrm{Cal} \cdot \mathrm{cm}^{-2} \cdot \mathrm{day}^{-1}\right)$

where $\mathrm{W}$ is the wind velocity in $\mathrm{m} \cdot \mathrm{s}^{-1}$.

Heat lost by evaporation in $\mathrm{Cal}^{\cdot} \mathrm{cm}^{-2} \cdot \mathrm{day}^{-1}$ is calculated by $\mathrm{Q}_{\mathrm{e}}=58.7 \cdot \mathrm{E}$, where $\mathrm{E}$ is the evaporated water in $\mathrm{mm} \cdot \mathrm{day}^{-1}$ (appendix 1).

Heat lost by surface ocean back radiation is given by $\mathrm{Q}_{\mathrm{bs}}=0.97 \cdot \sigma \cdot \mathrm{T}_{\mathrm{sur}}{ }^{4}\left(\sigma=11.7 \cdot 10^{-8}\right.$ $\left.\mathrm{Cal} \cdot \mathrm{cm}^{-2} \cdot \mathrm{day}^{-1} \cdot \mathrm{K}^{-1}\right)$, where the efficience of black body is supposed $97 \%$ (Otto, 1975).

Average heat loss by reflection (albedo) in this latitude is suposed to be $6 \%$ of irradiation (Otto, 1975). 


\section{Appendix 3: On the evaluation of averaged fluxes}

By means of equations [3] and [4], two sets of fluxes can be calculated: through salt $\left(Q_{x j}{ }^{S}, Q_{x j}{ }^{S}\right)$ and heat balances $\left(Q_{x j}{ }^{T}, Q_{x j 0}{ }^{T}\right.$, where the superindeces shows the thermohaline property involved in the computation of flux). These fluxes are, in general not equal. Each set satisfies its own balance, so that if we consider the residual anomaly in each box due one thermohaline propertie distribution $\delta \mathrm{M}^{\mathrm{N}}(\mathrm{M}, \mathrm{N}=\mathrm{S}, \mathrm{T})$ given by:

$\delta M^{N}=Q_{x j}{ }^{N} \cdot M_{j}-Q_{x 0 j}{ }^{N} \cdot M_{0 j}+Q_{x 0 i}{ }^{N} \cdot M_{0 i}-Q_{x i}{ }^{N} \cdot M_{i}+\left(V j+V_{0 j}\right) \cdot(d M / d t)-L M_{L}-R M_{R}$

$\delta \mathrm{M}^{\mathrm{N}}$ is a function of the fluxes $\left(\mathrm{Q}_{\mathrm{Xj}}{ }^{\mathrm{N}}, \mathrm{Q}_{\mathrm{X} 0 \mathrm{i}}{ }^{\mathrm{N}}\right)$. It is zero when $\mathrm{M}=\mathrm{N}$ but no othewise.

More realistic fluxes $\left(\mathrm{Q}_{\mathrm{xj}}, \mathrm{Q}_{\mathrm{xj} 0}\right)$ are computed by averaging with appropiate weighing both sets of fluxes. This is discussed next:

If a slight perturbation in the flux $(\delta Q)$ is introduced in the fluxes calculated from salt balance (the results will be the same if we had chosen the heat balance fluxes), the following fluxes would be obtained:

$\mathrm{Q}_{\mathrm{xj}}=\mathrm{Q}_{\mathrm{xj}} \mathrm{S}_{+} \mathrm{\delta Q} ; \quad \mathrm{Q}_{\mathrm{xj} 0}=\mathrm{Q}_{\mathrm{xj} 0} \mathrm{~S}_{+\delta \mathrm{Q}}$

By substitution of these values in [I], the errors take the linear form:

$$
\begin{aligned}
& \delta S=\delta S^{S}+\delta Q\left(S_{x 0 j}-S_{x j}\right) \\
& \delta T=\delta T^{S}+\delta Q\left(T_{x 0 j-} T_{x j}\right)
\end{aligned}
$$

Therefore, a perturbation in the fluxes generates linear and proportional anomalies in both thermohaline properties. If we take as this perturbation precisely the difference between both 
fluxes: $\delta Q=Q_{x j 0}{ }^{T}-Q_{x j 0} S$, we have, according to equation [II]: $Q_{x j}=Q_{x j}{ }^{T}$ and $Q_{x j 0}=Q_{x j}{ }^{T}$. Thus, substituting in eqs. [IIIa] and [IIIb], the anomalies of both variables would be:

$$
\begin{aligned}
& \delta S=\left(Q_{x j 0}{ }^{T-} Q_{x j 0}{ }^{S}\right) \cdot\left(S_{x j}-S_{x 0 j}\right) \\
& \delta T=\delta T^{S}+\left(Q_{x j 0}{ }^{T}-Q_{x j}{ }^{S}\right) \cdot\left(T_{x j}-T_{x 0 j}\right)=0
\end{aligned}
$$

For each set of results (sampling), we can define an error distribution function of the thermohaline properties:

$\Phi=\left[\left(\delta \mathrm{S} / \sigma_{\mathrm{S}}\right)^{2}+\left(\delta \mathrm{T} / \sigma_{\mathrm{T}}\right)^{2}\right]$

where $\sigma_{\mathrm{S}}{ }^{2}$ and $\sigma_{\mathrm{T}}{ }^{2}$ are the variances of saline and thermal balances between upper and lower layers for all boxes (j) and all samplings (J). Both these variances are introduced for giving $\Phi$ a dimensionless quality so that both termscan be compared to each other. Therefore:

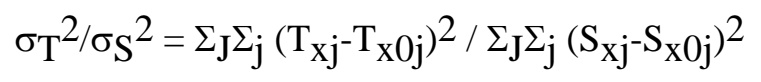

By substitution of [IV] in [V], we obtain:

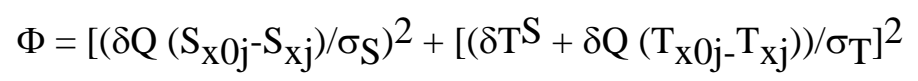

Minimising [VII] with respect to $\delta \mathrm{Q}$ gives an expression for the perturbation in the flux:

$$
\delta Q=-\left(T_{x 0 j}-T_{x j}\right) \cdot \delta T^{S} / \sigma_{T}^{2} /\left[\left(S_{x 0 j}-S_{x j}\right)^{2} / \sigma_{S}^{2}+\left(T_{x 0 j}-T_{x j}\right)^{2} / \sigma_{T}^{2}\right]
$$

By substituting in [VIIIa] the value of $\delta \mathrm{T}^{\mathrm{S}}$ given in [IV] we have:

$$
\delta Q=\left(T_{x 0 j}-T_{x j}\right)^{2} \cdot\left(Q_{x j 0} T_{-} Q_{x j 0} S / \sigma_{T} T^{2} /\left[\left(S_{x 0 j}-S_{x j}\right)^{2} / \sigma_{S}{ }^{2}+\left(T_{x 0 j}-T_{x j}\right)^{2} / \sigma_{T}{ }^{2}\right] \quad[V I I I b]\right.
$$


If [VIIIb] is introduced in [II], it gives the averaged fluxes from salt and temperature gradients:

$\left.Q_{x j}=\left[Q_{x j} S \cdot S_{x 0 j}-S_{x j}\right)^{2} / \sigma_{S}^{2}+Q_{x j}{ }^{T} \cdot\left(T_{x 0 j-} T_{x j}\right)^{2 / \sigma_{T}}{ }^{2}\right] /$

$/\left[\left(S_{x 0 j}-S_{x j}\right)^{2} / \sigma_{S}^{2}+\left(T_{x 0 j}-T_{x j}\right)^{2} / \sigma_{T}^{2}\right]$

Equation [IX] represents an ponderated average of fluxes according to the distribution of each thermohaline propertie. These fluxes minimize the $\Phi$ function, which represents the ponderated thermohaline error. The term $\left[\left(\mathrm{S}_{\mathrm{x} 0 \mathrm{j}}-\mathrm{S}_{\mathrm{Xj}}\right)^{2} / \sigma_{\mathrm{S}}{ }^{2}+\left(\mathrm{T}_{\mathrm{x} 0 \mathrm{j}-} \mathrm{T}_{\mathrm{xj}}\right)^{2} / \sigma_{\mathrm{T}}{ }^{2}\right]$ represents the thermohaline variance. The higher the variance is, the more accurately can the fluxes be computed.

Vertical diffusive fluxes (equs. [5] and [6]) are also averaged in the same way:

$Q_{M z j}=\left[Q_{M z j}{ }^{S} \cdot\left(S_{0 j}-S_{j}\right)^{2} / \sigma_{S}^{2}+Q_{M z j}{ }^{T} \cdot\left(T_{0 j}-T_{j}\right)^{2} / \sigma_{T}{ }^{2}\right] /\left[\left(S_{0 j}-S_{j}\right)^{2} / \sigma_{S}{ }^{2}+\left(T_{0 j}-T_{j}\right)^{2} / \sigma_{T}{ }^{2}\right]$

Due to the great spatial variability observed during the six mounths sampling, a value of ( $\left.\sigma_{\mathrm{T}} / \sigma_{\mathrm{S}}\right)^{2}$ (equation 6) was assigned for each box. The existence as well of a marked temporal variability, with a first "wet" period of more continental runoff (from the beggining to sampling 20), and a second "dry" one (sampling 20 onwards) when the river contribution is lower (figure 1) allows us to distinguish two sets of values of $\left(\sigma_{\mathrm{T}} / \sigma_{\mathrm{S}}\right)^{2}$ for each period (51 and 153 respectively for E4). 
Appendix 4. On the calculus of the flux in any intermediate day $\left(Q_{m}\right)$ :

The parabolic function that passes through $\left(\mathrm{Q}\left(\mathrm{J}^{\mathrm{n}-1}\right), \mathrm{J}^{\mathrm{n}-1}\right) ;\left(\mathrm{Q}\left(\mathrm{J}^{\mathrm{n}}\right), \mathrm{J}^{\mathrm{n}}\right)$ and $\left(\mathrm{Q}_{\mathrm{m}}\right.$, $\left.\mathrm{t}_{\mathrm{m}}=\left(\mathrm{t}_{1}+\mathrm{t}_{2}\right) / 2\right)$, is $\mathrm{Q}=a+b \cdot \mathrm{J}+c \cdot \mathrm{J}^{2}$; where:

$\mathrm{J}$ is the julian day and

$a=\mathrm{Q}_{\mathrm{m}}$,

$b=\left[\mathrm{Q}\left(\mathrm{J}^{\mathrm{n}}\right)-\mathrm{Q}\left(\mathrm{J}^{\mathrm{n}-1}\right)\right] /\left[\left(\mathrm{J}^{\mathrm{n}-1}\right)-\left(\mathrm{J}^{\mathrm{n}}\right)\right]$

$c=2 \cdot\left(\mathrm{Q}\left(\mathrm{J}^{\mathrm{n}-1}\right)+\mathrm{Q}\left(\mathrm{J}^{\mathrm{n}}\right)-2 \cdot \mathrm{Q}_{\mathrm{m}}\right) /\left[\left(\mathrm{J}^{\mathrm{n}}\right)-\left(\mathrm{J}^{\mathrm{n}}-1\right)\right]^{2}$

In this appendix we will solve the three integrals of equation [11]. If we assume a linear variation in $\mathrm{R}$, and $\mathrm{C}_{\mathrm{Q}}$, the second and third one are easily solved:

$\int_{J n-1}^{J^{n}} R \cdot N_{R} \cdot d t=N_{R} \cdot\left[R\left(J^{n}\right)+R(J n-1)\right] \cdot\left(J^{n}-J n-1\right) / 2$,
$\int_{J n-1}^{J^{n}} C_{Q} \cdot d t=\left[C_{Q}\left(J^{n}\right)+C_{Q}\left(J^{n-1}\right)\right] \cdot\left(J^{n}-J n-1\right) / 2$.

All terms of these two integrals are known. For the resolution of the first integral in [11], we assume a linear variation of $\mathrm{N}_{\mathrm{i}}$ with time and parabolic variation of $\mathrm{Q}_{\mathrm{i}}$ :

$\int_{J n-1}^{J^{n}} Q_{i \cdot} \cdot N_{i} \cdot d t=\left\{2 \cdot\left[N_{i}\left(J^{n}\right)+N_{i}\left(J^{n-1}\right)\right] \cdot Q_{m}+Q\left(J^{n-1}\right) \cdot N\left(J^{n-1}\right)+Q\left(J^{n}\right) \cdot N\left(J^{n}\right)\right\} \cdot\left(J^{n}-J^{n-1}\right) / 6$

Thus, in equation [11] we know all terms except $\mathrm{Q}_{\mathrm{m}}$. Therefore, we can calculate the value of $\mathrm{Q}_{\mathrm{m}}$ that satisfies equation [11]. Once computed, $\mathrm{Q}_{\mathrm{m}}$ is weigh-averaged according to salinity and temperature gradients (see appendix 3). 


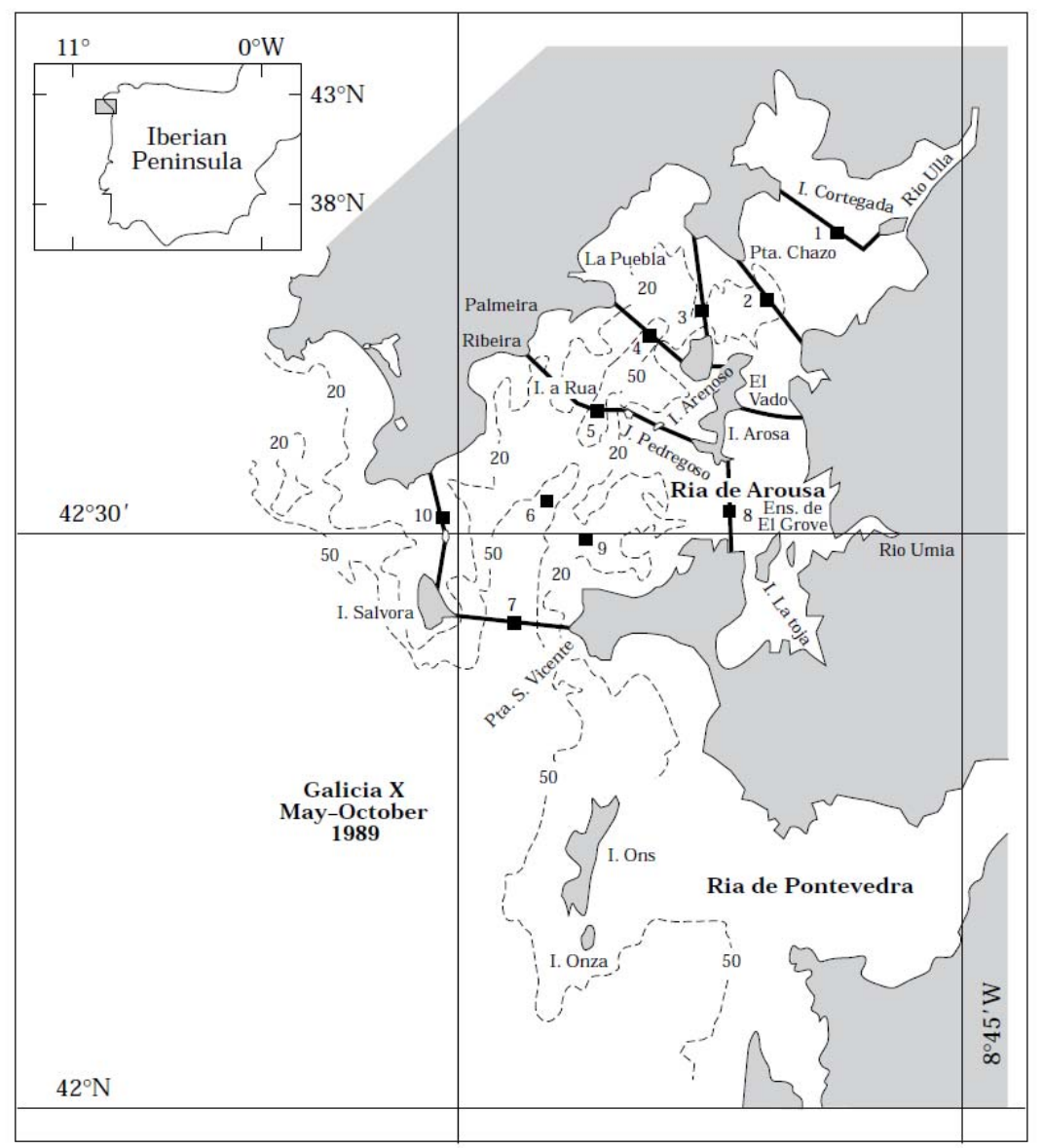

Figure 1 

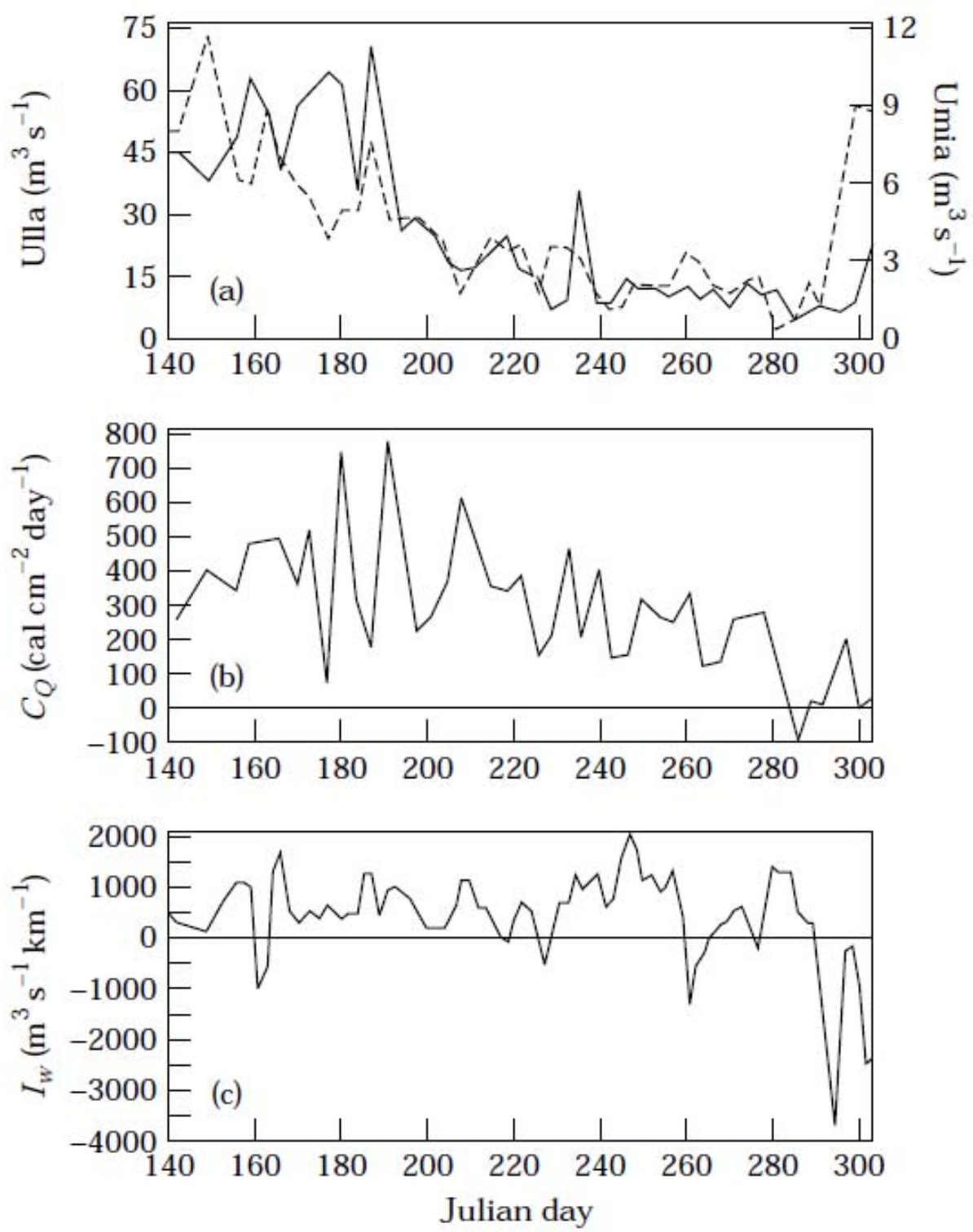

Figure 2 


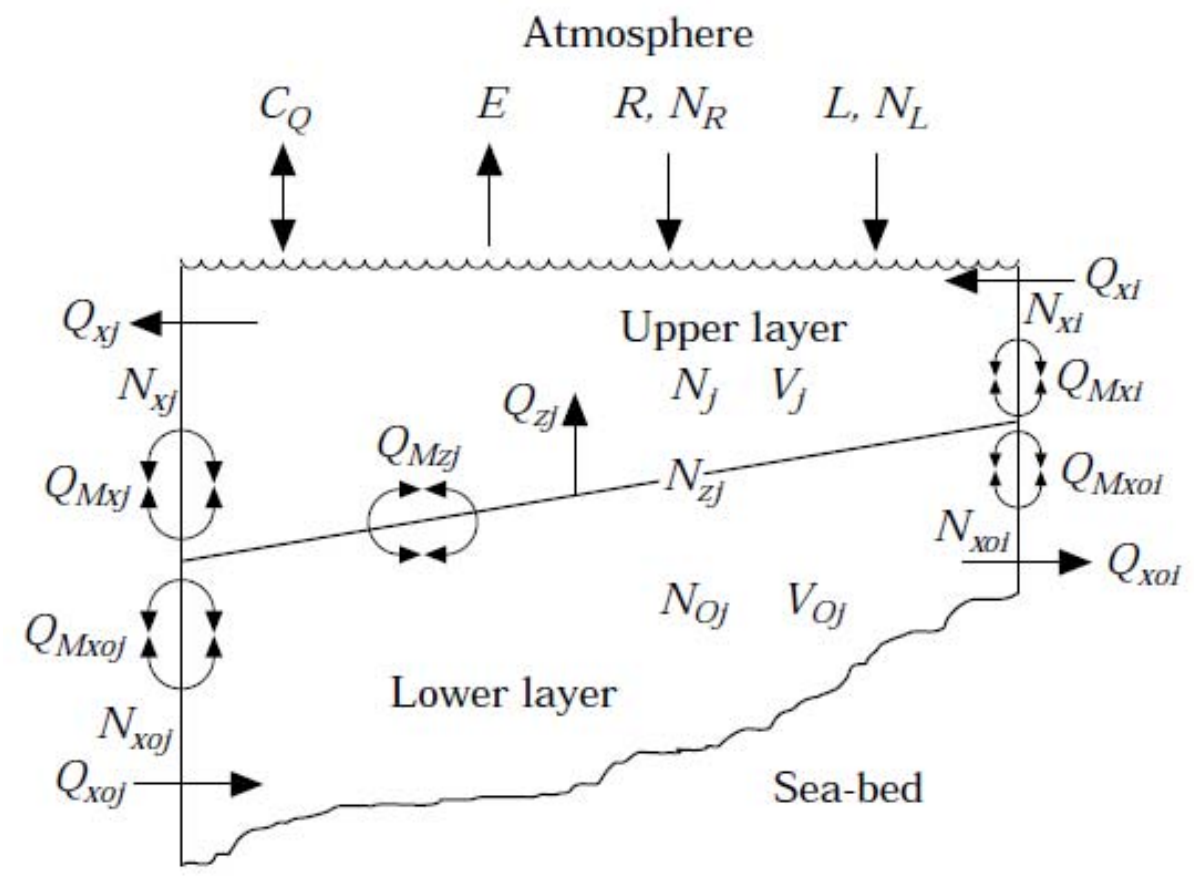

Figure 3 


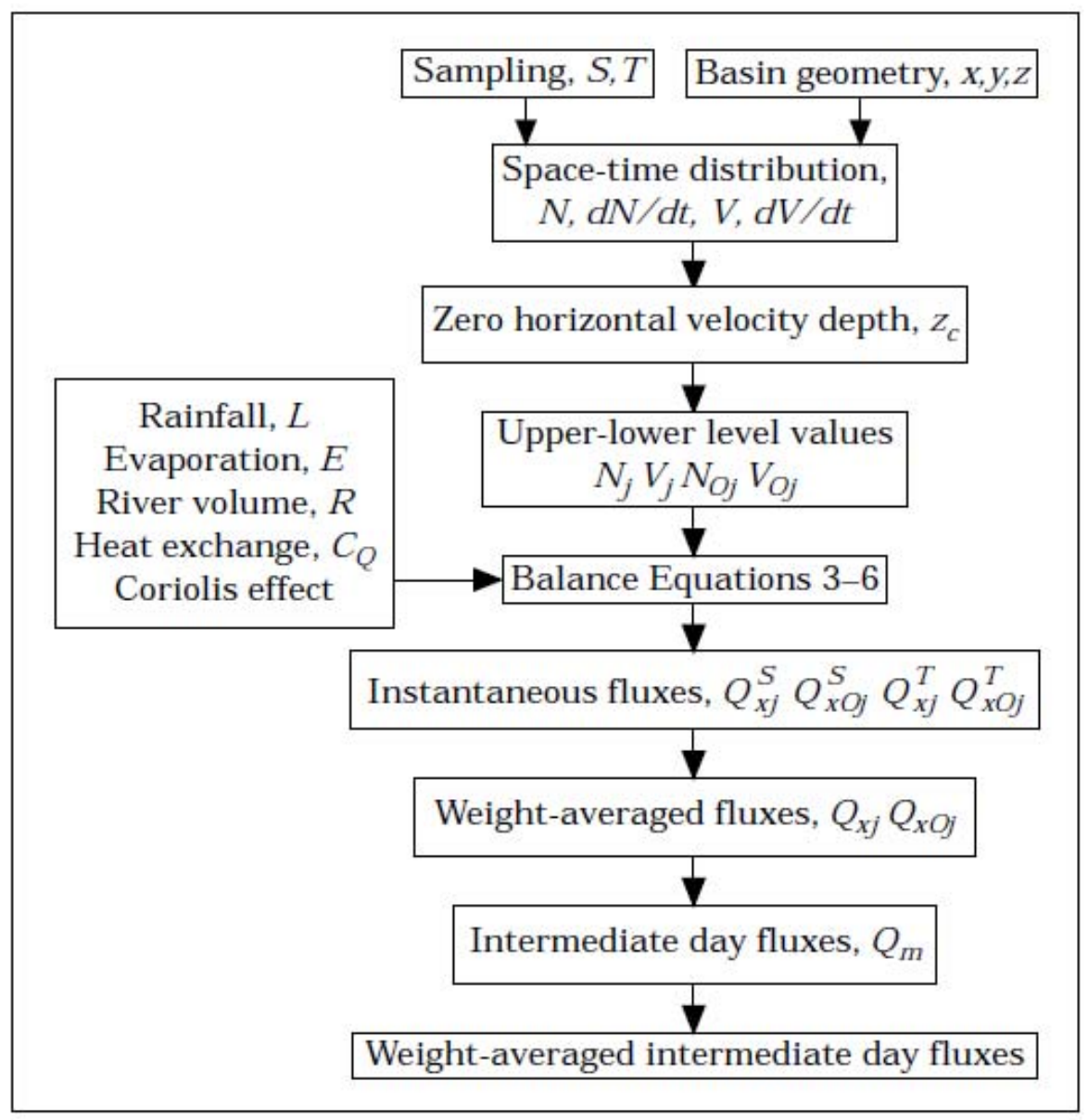

Figure 4 


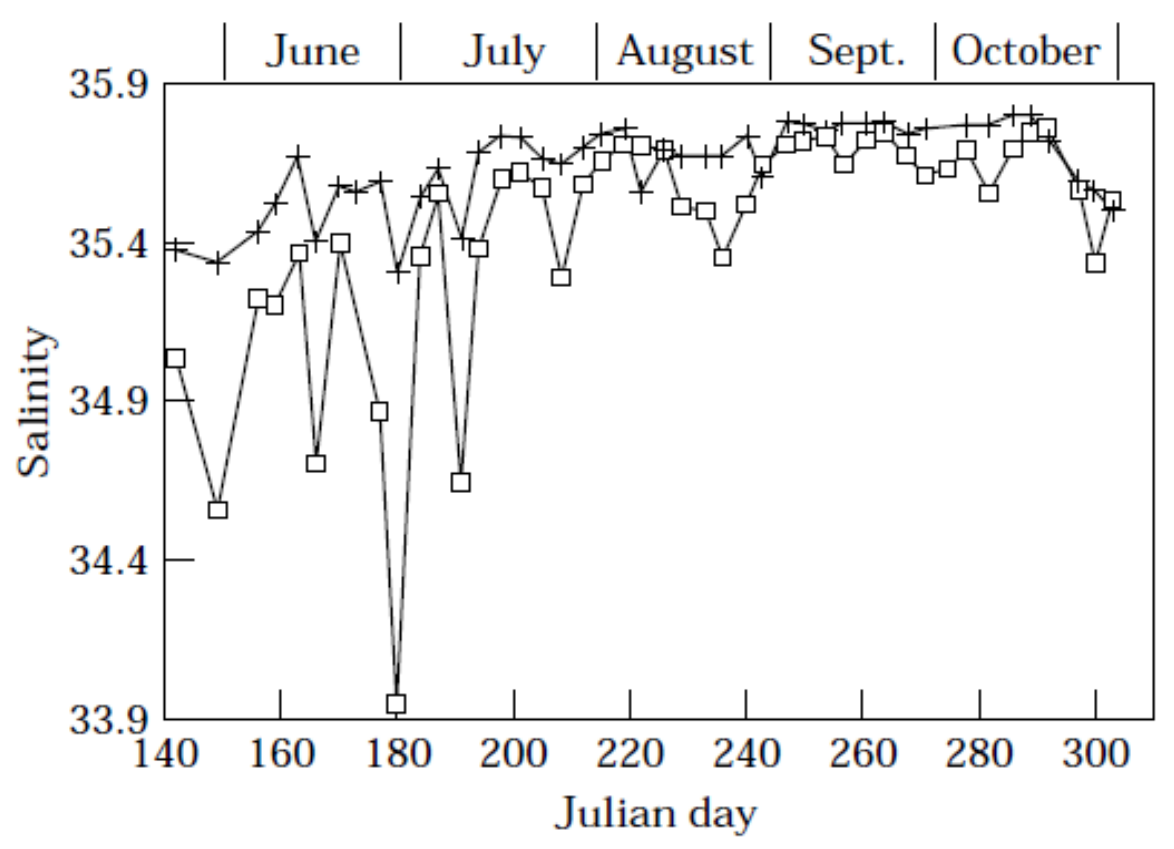

Figure 5 

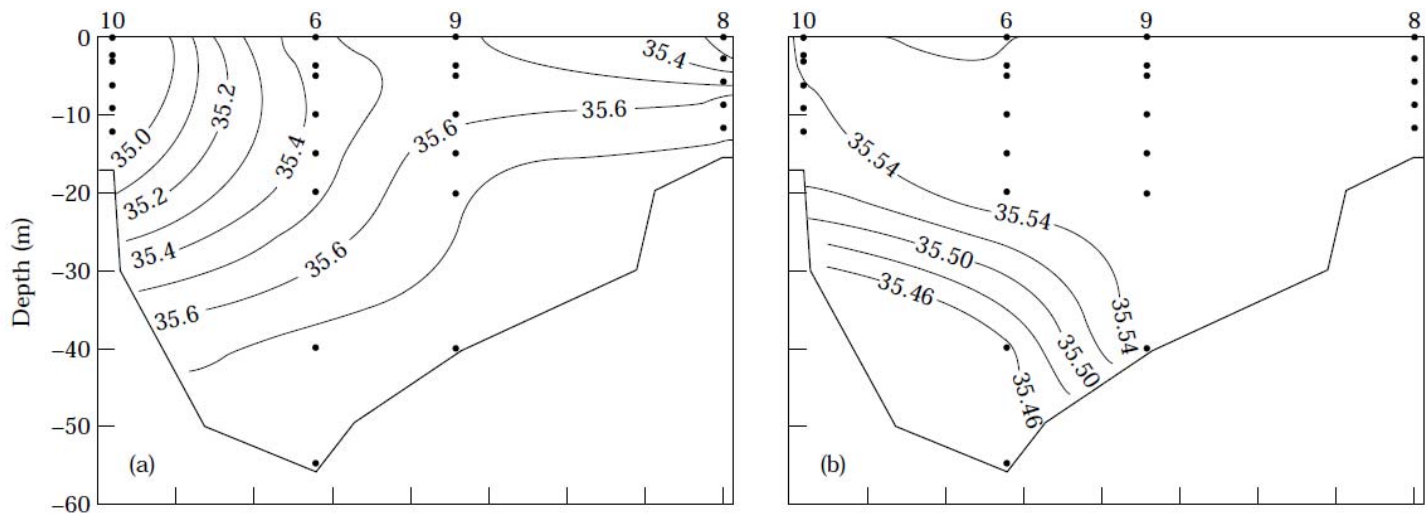

Figure 6 


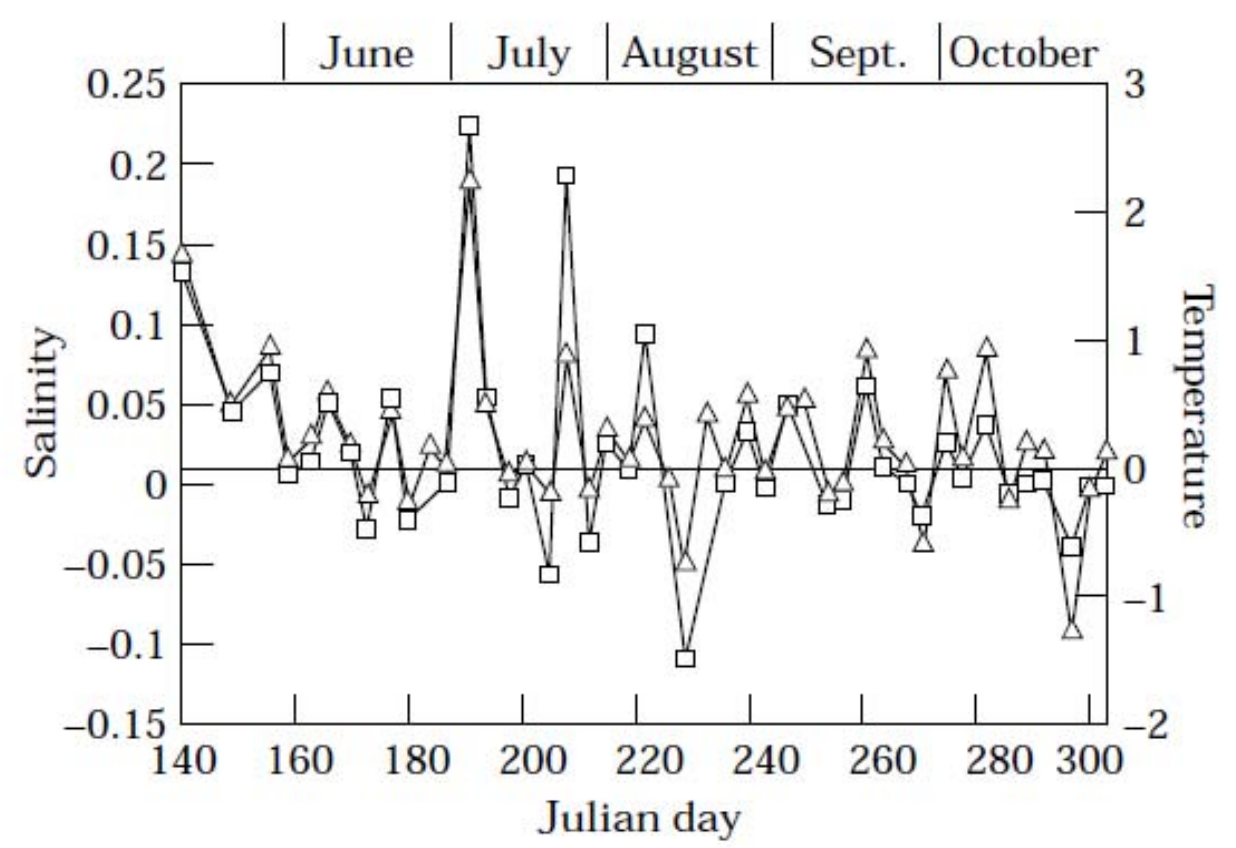

Figure 7 

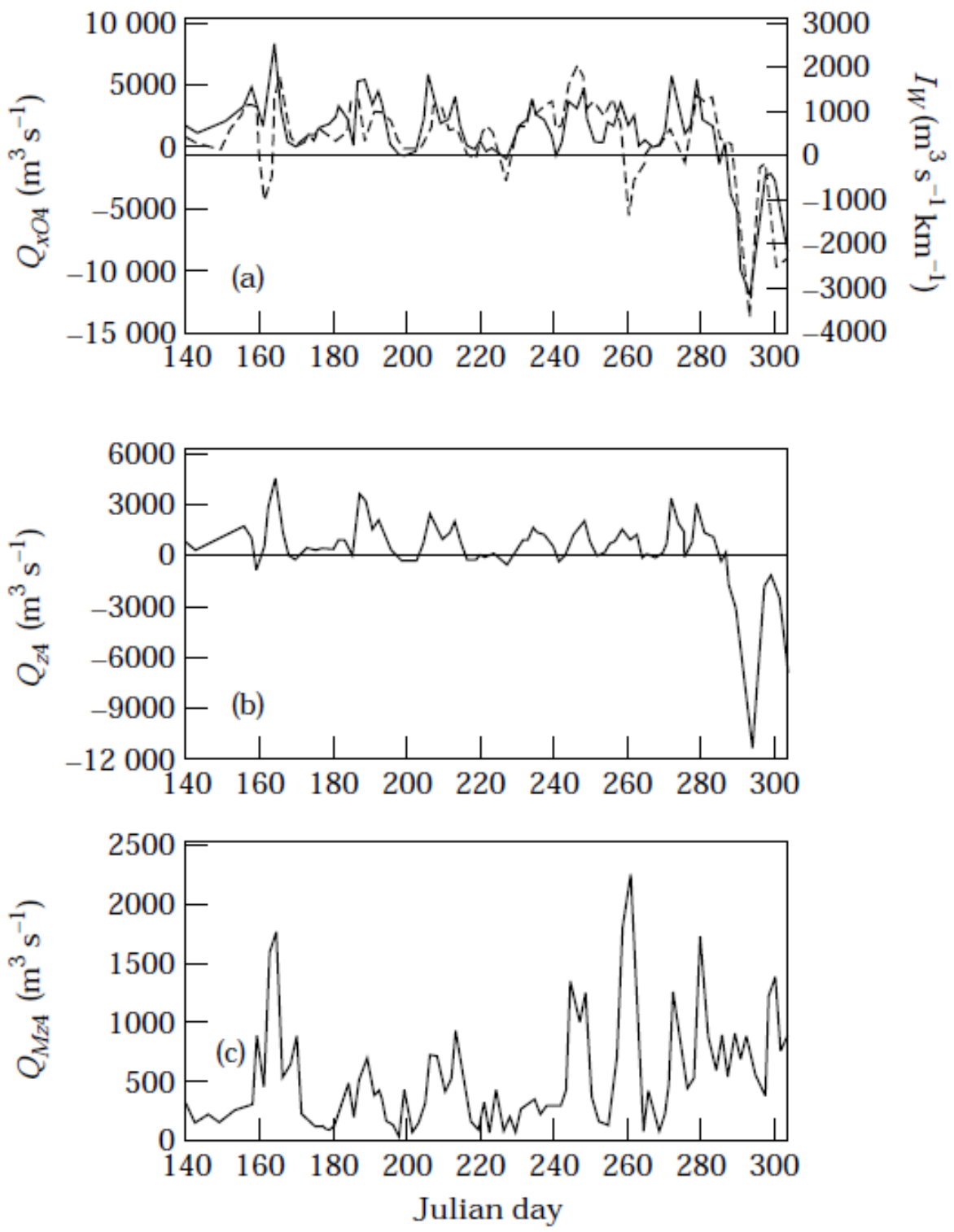

Figure 8 


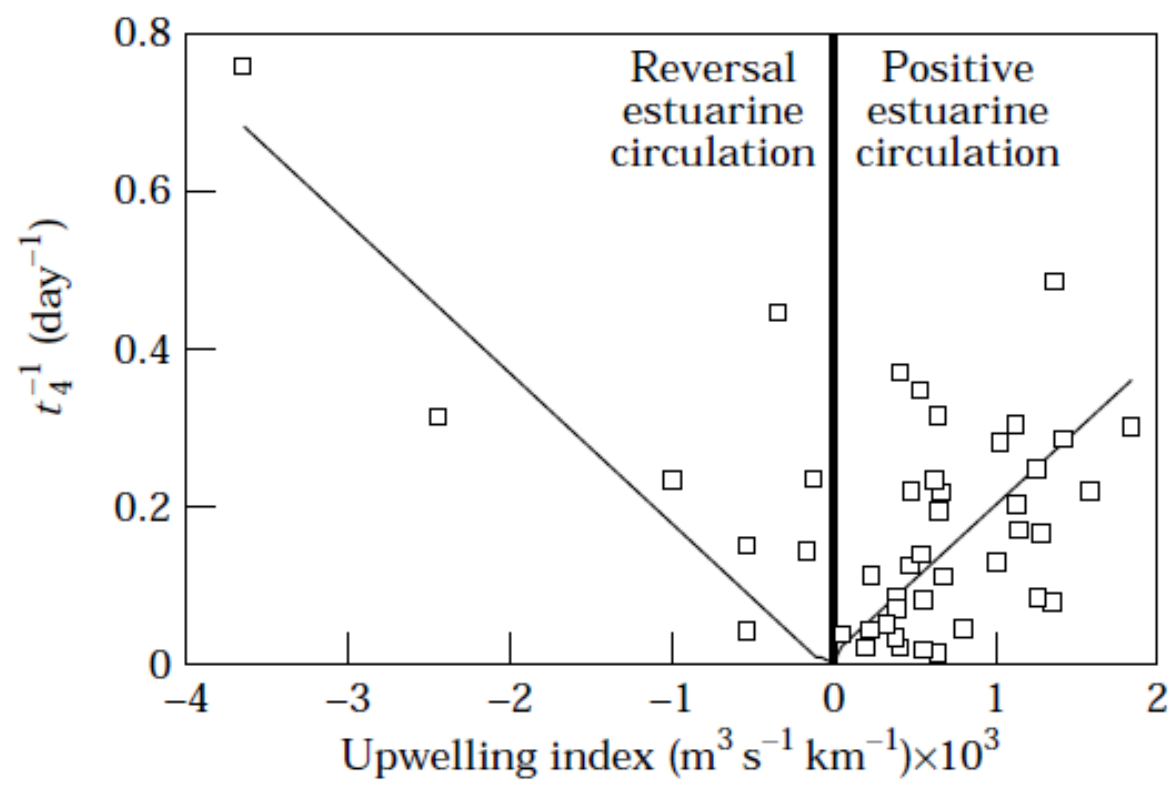

Figure 9 


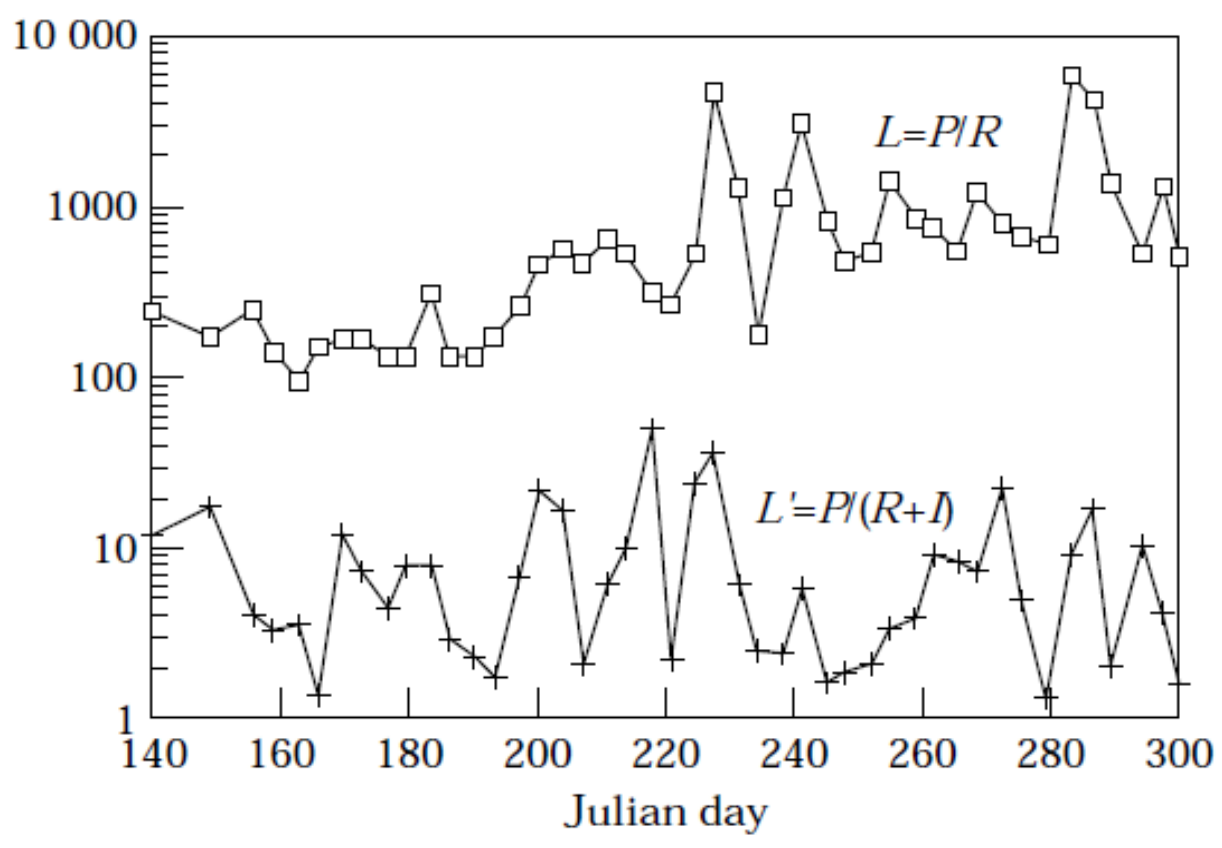

Figure 10 